\title{
Career Stability in 14 Finnish Industrial Employee Cohorts in 1988-2015'
}

\section{Satu Ojala ${ }^{2}$}

University Lecturer, Tampere University, Faculty of Social Sciences, Finland

\section{Pasi Pyöriä}

Senior Lecturer, Tampere University, Faculty of Social Sciences, Finland

\section{Aart-Jan Riekhoff}

Senior Researcher, Finnish Centre for Pensions, Finland

\begin{abstract}
It is often argued that global competition and technological development have made industrial jobs more unstable. In this article, we ask how career stability has evolved in the Finnish forest, metal, and chemical industries, comparing 14 cohorts (age groups) by gender and educational level. We focus on industrial employees born in 1958-1971 and compare their career stability at ages 30-44 using Statistics Finland's linked employer-employee data from 1988 to 2015 and an application of sequence analysis. We analyze career stability over time by examining annual main labor market statuses (employed, unemployed, student, disabled, retired, out of the labor force), adding estimators for workplace and industry changes. The results show no evidence of career destabilization across the cohorts, but they do reveal persistent inequalities between industrial employees with low and high levels of education, and between men and women.
\end{abstract}

\section{KEYWORDS}

Career / job stability / industry / linked employer-employee data / sequence analysis

\section{Introduction}

he labor market is in a constant state of flux, driven by global competition, cyclical fluctuation, and rapid technological development. It has been postulated that we are now witnessing a deepening segmentation and downward rather than upward mobility of the middle segment of the labor force, a tendency that may be strengthened by automation and digitalization (Asplund et al. 2011; Autor 2014; Goos et al. 2014; Kalleberg 2018).

Theories of job polarization suggest that these changes are leading to the creation of low-skill and high-skill jobs, at the same time as the middle is being hollowed out, albeit the evidence depends on the time period and countries selected for the analysis (Bárány \& Siegel 2018; Cirillo 2018; Horemans 2016; Salvatori 2018). For example, it is feared that the emerging platform economy, based on digital matchmakers between the supply

\footnotetext{
${ }^{1}$ You can find this text and its DOI at https://tidsskrift.dk/njwls/index.

${ }^{2}$ Corresponding author: Satu Ojala. E-mail: satu.ojala@tuni.fi.
} 
and demand of labor, may encourage new uses of the workforce that will accelerate the growth of low-paid work and involuntary self-employment (Eurofound 2018). At the other end of the spectrum, highly educated employees are expected to have increasingly specialized skills and a continuous readiness to meet the changing skill requirements of current and emerging jobs.

It has also been argued that the standard employment relationship - continuous, fulltime employment with a single employer over the employee's life course - is giving way to atypical employment. According to this position, increasing numbers of wage earners are running the risk of falling into precariousness, characterized by temporary contracts, spells of unemployment, deteriorating working conditions, poor prospects, and low income (Kalleberg, 2018). In particular, there has been much concern over the prospects of younger cohorts to gain a foothold in the labor market and to earn a decent living (France 2016).

Furthermore, it has been hypothesized that the alleged decline of the standard employment relationship has coincided with a fragmentation of work careers (Potter 2015), meaning greater volatility, heterogeneity, and unpredictability in career trajectories (Kalleberg \& Mouw 2018). In this article, we focus on work careers. We use career fragmentation as an umbrella term and divide the hypotheses concerning it in two dimensions: we assess career de/stabilization and de/standardization by drawing on a rich and extensive register dataset spanning a period of several decades. We ask how work careers in Finland have evolved in specific industrial sectors.

We focus on three major Finnish export industries, analyzing work careers in the forest, metal, and chemical sectors. Together, these industries represent the backbone of the Finnish economy. However, we exclude the information and communication technology (ICT) sector because it has been extensively studied before (see, e.g., Nikulainen \& Pajarinen 2013). In recent decades, the sectors examined in the present study have been exposed to globalization and changes in international trade, exogenous shocks (economic crises), and technological restructuring. On this basis, it has often been argued that technological automation and deindustrialization (the shift from manufacturing to services) may bring an end to life-long careers in industrial manufacturing.

Using linked employer-employee data (FOLK) compiled by Statistics Finland for the period from 1988 to 2015, we compare the careers of industrial employees born in 19581971 at ages $30-44$. Our focus is on the age and period of life when people have completed their education and when, in ideal conditions, careers are expected to stabilize and become upwardly mobile in terms of career progression. However, this 'mid-career' phase remains less studied compared to early and late careers (Brzinsky-Fay \& Solga 2016; Riekhoff 2018), even though it is a crucial time for family formation and often marks a period when employees seek promotional opportunities or new career alternatives (Schellenberg et al. 2016). Studies have also emphasized that mid-careers may have a lasting impact on later working life, retirement, and well-being in older age (Halpern-Manners et al. 2015).

We therefore set out to analyze mid-career trajectories of forest, metal, and chemical industry employees by examining their annual main labor market statuses (employed, unemployed, student, disabled, retired, out of the labor force), adding estimators for changes of workplace and industry. We separated the analyses by gender and educational attainment, as these factors are determinants of career trajectories (Järvinen et al. 2020). We will test the hypothesis that younger cohorts have endured more fragmented mid-careers than older cohorts (e.g., France 2016). Moreover, since population-level studies suggest only modest changes in careers across generations (Becker \& Blossfeld 2017; Hollister 2011; Stawarz

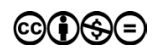


2018; Van Winkle \& Fasang 2017), we also hypothesize that inequality between industrial employees with low and high levels of education, and between men and women, persists. Finally, we hypothesize that economic fluctuations continue to play an important role in career instability. Our methodological approach is an application of sequence analysis that is suitable for estimating the stability of careers across cohorts and over time.

The article is structured as follows. We begin by defining the concepts of career de/ stabilization and de/standardization and present state-of-the-art empirical knowledge from different countries. We then move on to discuss the context of our study, that is, characterize the Finnish industrial sector as part of an open economy exposed to global competition and technological and cyclical changes. Next, we introduce our data and methods, and then present the results based on the sequence analysis. Finally, we proceed to discuss the findings and implications of our research.

\section{Research framework: career stability versus fragmentation}

It remains a matter of dispute whether there ever existed a golden age of stable employment relationships (Pyöriä \& Ojala 2016; Pyöriä et al. 2017; Rasmussen et al. 2019). In contrast to what is often suggested, insecurity and high mobility rates are necessary functions of the labor market. A high number of transitions between employment statuses is particularly pertinent to Nordic and other dynamic labor markets (Möhring 2016). Indeed, work careers are constantly evolving in tandem with the changing supply and demand of labor.

There is no single way of defining and operationalizing work careers. Earlier research has often focused on changes in certain types of employment (e.g., temporary, part-time, or self-employed), on single transitions (e.g., between unemployment and employment or between temporary and permanent positions) (Kalleberg \& Mouw 2018), or recently, on life courses by examining career spells that encompass more than one transition, and on changes between individuals and cohorts (e.g., Aisenbrey \& Fasang 2017; Möhring 2016; Riekhoff 2018).

In simple terms, 'career stability' refers to the absence of spells out of employment, whereas 'career fragmentation' implies some type of puzzle made up of several pieces. The latter term also suggests a process, an evolution towards a deepening state of fragmentation. Therefore, careers should be studied over time. In order to examine spells in employment and to assess transition rates between employment, nonemployment, and different jobs over time, we need longitudinal data (Barone \& Schizzerotto 2011; Bukodi \& Goldthorpe 2011).

Career fragmentation is used here as an umbrella term, with two main dimensions (Brückner \& Mayer 2005). First, it can occur within individuals' careers over time, indicating increasing complexity due to transitions between and in and out of jobs. This process has been called 'differentiation' or 'de-stabilization' of (working) life courses. Second, career de-standardization refers to people's careers becoming less and less alike between cohorts. This refers to increasing heterogeneity between individual career statuses at certain points in time, that is, that individuals are increasingly in different statutes at each age (Riekhoff 2018). The opposite of career fragmentation, in essence, is continuous or permanent employment, preferably of the same type and with the same employer, without deterioration between cohorts. 
Despite commonly held assumptions, earlier international longitudinal analyses have found no significant changes in the work careers of employed populations over time, either in the US or in Europe. The empirical evidence contradicts the fragmentation hypothesis (Järvinen et al. 2020; Rokkanen \& Uusitalo 2013), or supports only modest changes (Biemann et al. 2011; Hollister 2011; Stawarz 2018; Van Winkle \& Fasang 2017). Stawarz (2018), for example, has observed that once a person is employed, there are only modest changes in intragenerational social mobility over time. Stawarz compared 20-year-long careers in German cohorts born in the 1930s-1980s, and found some increase in career heterogeneity in men, as measured by the international standard classification of occupations (ISCO) between cohorts, as well as in inter- and intra-firm transitions. Becker and Blossfeld (2017), using the German life history data, observed that younger labor market entrants 'start their careers at increasingly higher average level of job attainment', following their higher educational attainment. However, they also observed increased downward mobility, warning us about deepening polarization.

Averages, of course, conceal the fact that there are segments in the workforce that have less stable careers (Bachmann \& Felder 2018; Becker \& Blossfeld 2017; Soininen 2015). For one thing, careers continue to remain gendered. In many industrial economies women's labor market participation is increasingly equal to men's, but even highly educated young women tend to have more fragmented careers, earn less than young men and take longer parental leaves (Aisenbrey \& Fasang 2017; Kuitto et al. 2019; Möhring 2016; Stawarz 2018). Along with unemployment, parental leaves are the main reason for early and mid-career breaks (Aisenbrey \& Fasang 2017; Brückner \& Mayer 2005; Kuitto et al. 2019). After family formation, women often enter part-time jobs, switch industries, and are exposed to downward mobility and lower wages (Brückner \& Mayer 2005; Buchmann et al. 2010; Cech \& Blair-Loy 2019; Stawarz 2018). If displaced, women have a harder time regaining their previous earnings level than men do (Jolkkonen et al. 2012). All in all, men typically have more stable careers than women (Schellenberg et al. 2016; Stawarz 2018).

Another source of segmentation is the skill-division of the workforce. According to Böckerman et al. (2012), who studied the firm-level effects of technology on jobs, employees in routine tasks were somewhat more exposed to unemployment risks. However, the majority of them were able to find a new job and did not enter long-term unemployment. Jolkkonen et al. (2012) reported that white-collar employees were more likely to find a new job after displacement. According to Stawarz (2018), public sector careers and skilled manual and white-collar workers' careers were more stable than unskilled manual laborers' careers, which involved more frequent inter-firm transitions. Based on cohort comparisons, Stawarz also observed that older cohorts born in the 1930s-1950s had the most stable careers. However, Stawarz found only modest changes in younger cohorts' careers.

Buchmann et al. (2010) have listed other drivers of recent labor market dualism, including the differentiated effects of occupational segregation on career outcomes, firms' recruitment and reward policies, gendered expectations of traditional labor divisions affecting women's employment, firm size (smaller firms lacking financial reserves), and regional issues. Furthermore, Bachmann and Felder (2018) observed an underlying trend of shortened job tenure in the European workforce between 2002 and 2012, after accounting for the aging of the workforce and controlling for the financial crisis. They found that the loss of short-tenured jobs in few countries such as Spain partially explains the lengthening of tenures in the aftermath of the crisis (short spells disappear from the data).

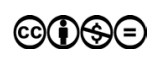


Overall, the drivers that determine how careers unfold are many and varied. In the Nordic countries, the labor markets are 'flexibly standardized', combining high levels of both stable careers and individual turnovers between statuses (see, Möhring 2016; Soininen 2015). This is in contrast to other European employment regimes, which range from highly stable careers in the Czech Republic to a destabilized, gendered, and deeply segmented labor market in Greece and Spain (Möhring 2016), reflecting the level of employment protection in each country (Bachmann \& Felder 2018). The data used in these longitudinal career studies are mostly based on surveying representative populations using retrospective measures on educational and employment histories. Some analyses are based on official registers (Järvinen et al. 2020; Rokkanen \& Uusitalo 2011; Soininen 2015). The measurement tools remain heterogeneous: researchers have evaluated changes in occupations, wages, spells in employment, or latent career trajectories. All conclusions, however, suggest modest rather than large changes in work careers despite the measure used. We next turn to discuss the specifics of the Finnish labor market, the case highlighted in the present study.

\section{Finnish export industries: exposed to structural and cyclical fluctuation in an open economy}

\section{Three central export industries}

Industrialization in Finland started from the forest industry in the late 19th century. Today, this sector continues to show strong performance, accounting for $12 \%$ of total employment in manufacturing industries. The metal industry also goes back a long way. After World War II, the sector quickly modernized, and today it accounts for over $40 \%$ of all industrial manufacturing jobs. The chemical industry emerged to prominence more recently. Since the decline of the Nokia-driven ICT sector in the 2000s, the chemical industry has become one of Finland's most valuable producers of high-tech materials, accounting for $10 \%$ of manufacturing employment.

\section{Vulnerability to economic shocks}

Finland makes an interesting case for the present study, as it represents both rapid modernization and flexible adaptation to economic and technological change (Pyöriä 2006). Finland evolved from an agrarian to an industrialized society later than most other European countries. When the cohorts of our study were born, strong service sector growth was turning Finland into a post-industrialized society. The economy boomed in the 1980s, but just a decade later, the country slipped into a banking crisis and recession.

In the early 1990s, Finland fell into a recession that was more severe than in any other European country (Kalela et al. 2001; Pyöriä 2006). In 1990, economic growth grinded to a halt, and in 1991, GDP declined by 6.3 per cent. The fall continued for another two years $(-3.3 \%$ in 1992 and $-1.1 \%$ in 1993). Thousands of jobs were lost and unemployment skyrocketed from $3 \%$ in 1990 to over $16 \%$ in 1994 . However, the recovery that followed was equally dramatic, spearheaded by the country's newly emerged ICT sector that spurred growth and innovation in traditional industries as well. 
The Finnish economy peaked in early 2008 before the onset of the global financial crisis. In 2008-2009, a long period of strong economic growth ended abruptly, exposing the vulnerability of the small national economy to international trends. By the end of 2008 , GDP growth came to a halt. In 2009, GDP fell by over $8 \%$, and in the 2010 s growth remained modest. Despite the severity of the shock, continued strength in public and private services prevented a sharp rise in unemployment. Against this background, it is interesting to see how career stability has evolved in the export sectors most vulnerable to exogenous shocks.

\section{Highly skilled workforce}

The characteristics of the Finnish workforce have changed significantly during the time span of our study. In particular, educational levels have risen across the board (Figure 1). From 1988 to 2015, the share of tertiary educated employees has increased significantly. Among women, the share of those with a higher education as a proportion of the total population increased from $17 \%$ to $33 \%$ and among men from $18 \%$ to $26 \%$. In 2015 , $44 \%$ of men and $38 \%$ of women had a secondary (mainly vocational) education. Over the period under investigation, then, women have overtaken men in terms of educational attainment. At the same time, the proportion of the population with no more than basic education has almost halved. The cohorts selected for our investigation were born in 1958-1971 and recruited in the study in the year they turned 30. Most typically, they have an upper secondary vocational education (see Table 1).

The three export industries in focus employ a wide range of workers with various backgrounds, including less educated auxiliary staff and highly educated research and development personnel. Compared to other industries, the workforce in the chemical industry is highly skilled. One of the occupational categories in this sector is female-dominated, namely laboratory assistants and technicians. The other industries are sharply and deeply segmented by gender. Overall, only one-fifth of the industrial employees in our sample are women (Table 1). Despite the segregation, both female and male industry employees typically work full-time in dual-earning households, reflecting the high Nordic level of gender equality in terms of time allocation to wage employment (Anxo et al. 2007). In principle, women have equal opportunities with men to carve out careers for themselves as parental leaves are compensated and all families are entitled to public day care services. However, most family leaves are in fact used by women, and their careers often decline at fertility age when compared to men (Kuitto et al. 2019). This also affects industrial careers.

Industrial employees in Finland are a segmented and heterogeneous group, which is only to be expected given that the proportion of low-educated industrial workers has consistently decreased since the 1980s at the same time as the educational level of the working-age population as a whole has risen. Our three export industries account for around one-third of all industrial jobs in Finland. As shown in Figure 2, the chemical industry has had relatively stable rates of employment since the 1980s, while the number of people working in the forest industry has steadily fallen. The metal industry, on the other hand, has seen the highest level of cyclical fluctuations. One of the features shared in common by all three industries is that during the period under investigation (1988-2005), they have increasingly outsourced services in order to reorganize their division of labor. 
Figure I Population aged 15 or over by level of education and gender, 1970-20 I8.

Source: Educational structure of population, Statistics Finland 2020, own calculations.

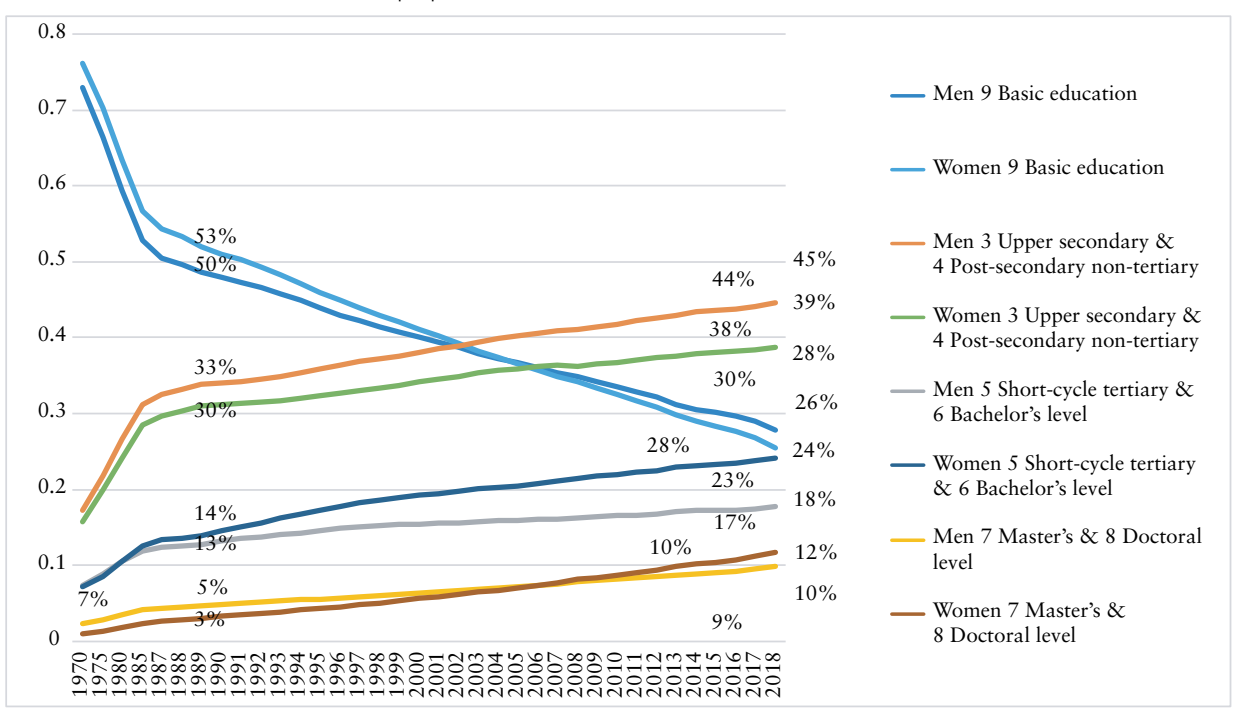

Table I Descriptive statistics

\begin{tabular}{llllll}
\hline Characteristics & \multicolumn{7}{c}{$\%$} & & $\%$ \\
\hline Birth year & 1958 & 8.2 & Gender & Women & 19.1 \\
\hline 1959 & 8.2 & & Men & 80.9 \\
\hline 1960 & 8.1 & Industry & Chemical & 19.0 \\
\hline 1961 & 7.1 & & Forestry & 31.0 \\
\hline 1962 & 6.3 & & Metal & 50.0 \\
\hline 1963 & 6.2 & Education & Lower & 17.8 \\
\hline 1964 & 6.7 & & Intermediate & 64.7 \\
\hline 1965 & 7.0 & & Higher & 17.5 \\
\hline 1966 & 6.8 & & & \\
\hline 1967 & 7.2 & & & \\
\hline 1968 & 7.5 & $\mathrm{~N}$ & \\
\hline 1969 & 6.9 & & & \\
\hline 1970 & 7.2 & & & \\
\hline
\end{tabular}

This reflects the growing economic and political pressures to make more flexible use of the workforce (Hyman 2018; Lehndorff et al. 2018).

However, nonstandard contracts are not common in the industrial core labor force. Rather, industrial firms have increasingly chosen to outsource such functions as cleaning, 
Figure 2 Total number of employed persons in forest, metal, and chemical industries at year-end 1988-2015. Source: Statistics Finland, FOLK, own calculations.

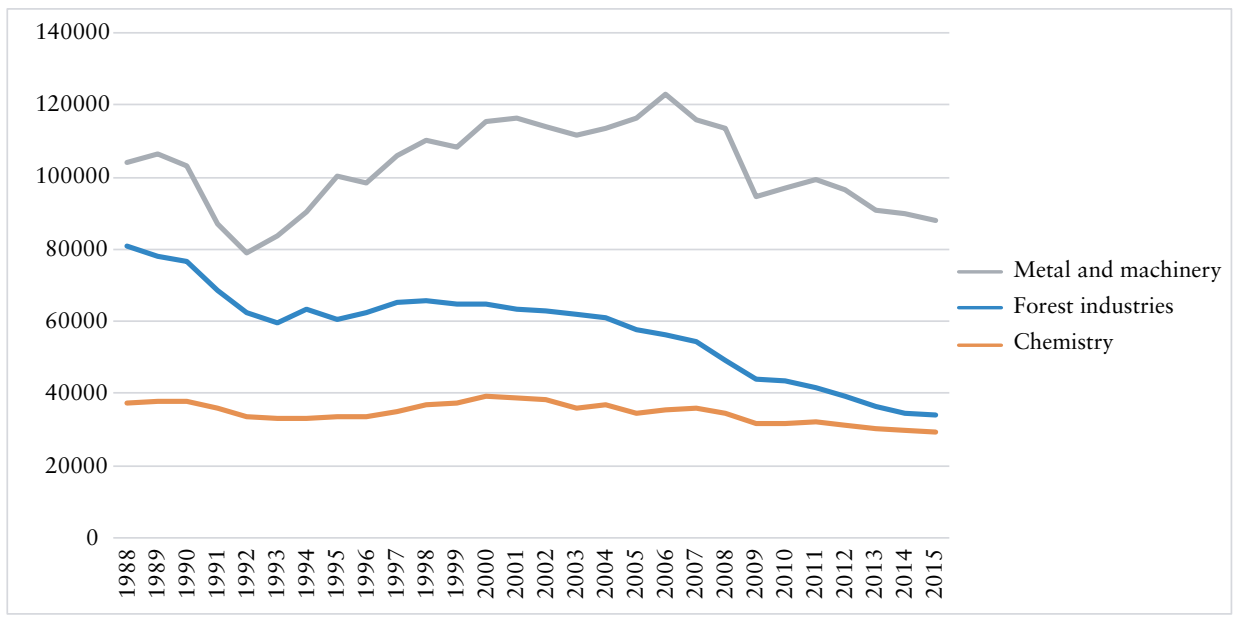

property maintenance, and food and meals services. This trend has also been extended to white-collar work, with a view to promoting flexible uses of the workforce (Allvin et al. 2011). In the context of industrial work, accounting, software development, and other knowledge-intensive services are often outsourced (or offshored) to subcontractors or strategic business partners. Business cycle contractions have also been found to have profound effects on uses of the workforce (López-Andreu \& Rubery 2018). Toward the end of the time span covered by our study, then, the number of personnel directly employed by the industrial sector has decreased, at the same time as industrial firms have shown a strong or fluctuating performance in terms of annual revenue and other economic indicators.

\section{Data and methods}

General employment trends are relatively easy to follow using official labor force statistics and annual cross-sections. The analysis of work careers, by contrast, is a much more complex matter and requires longitudinal data. Longitudinal designs allow us to estimate the effects of cyclical and structural labor market changes. Our focus in this study is on mid-career stability, an aspect often neglected in the research literature (cf. Buchmann et al. 2010; Kohli 2007).

In order to identify trends and factors influencing jobs and the alleged fragmentation of careers in Finnish export industries, we deploy FOLK - a massive register-based remote access dataset that has been produced annually by Statistics Finland since 1988. FOLK (formerly FLEED - Finnish Longitudinal Employer-Employee Data) covers the whole working age population and extends from 1988 to 2015. We have chosen our cohorts based on the total data of persons aged 15-70 and residing permanently in Finland. The total data for each year comprises some 3.6 million persons (the current population of Finland is 5.5 million). Persons can be followed over time as long as they are alive and living in Finland. Compiled by merging various administrative registers, 
FOLK includes a broad range of individual variables linked with enterprise and establishment variables. Linked employer-employee data are becoming increasingly important sources in research on career stability (Jolkkonen et al. 2012; Soininen 2015).

The total FOLK data has distinct advantages over sample surveys, although no data source should be considered error-free, and official registers do not collect details for example about the type of employment contract (Pavlopoulos \& Vermunt 2015). The measures we use, derived systematically from official population, income and education registers, are highly accurate and reliable, whereas retrospective surveys suffer from respondents' memory bias, a problem that is particularly pronounced in the context of career research (Manzoni et al. 2010). A great advantage of our data is that each individual, enterprise, and establishment is identified by a time-invariant encrypted code. With FOLK, it is possible to follow the same employees over time and determine whether career complexity has increased and, if that is the case, to what to extent this is due to changes in labor market statuses or workplace or industry switches. The FOLK-register is unique, as it accurately represents even small subpopulations.

Another major strength of our register data is that the problem of missing data is virtually non-existent: individuals drop out during the follow-up only if they die or move out of the country, and there is no item nonresponse. Many study designs, by contrast, often suffer from initial nonresponse during the recruitment in the baseline survey and successive dropout at each time point, thus threatening the validity of the results (de Leeuw \& Lugtig 2015). By international standards, FOLK is comprehensive, covers a uniquely long time span, and offers great potential for insights into the development of work careers in the nexus between 'individual' (social background, education, earlier career) and 'structure' (establishment effects, cyclical macroeconomic fluctuations).

In this study, we use FOLK to determine annual main labor market statuses (employed, unemployed, student, disabled, retired, out of labor force), adding estimators for changes of workplace and industry. Statistics Finland (2004) has put great effort to ensure the accuracy of these variables, as defining main type of activity is the primary task of employment statistics. The variable 'main labor market status' is derived from official registers and based on the duration (longest spell during a year) or timing (end of year) of statuses during a year. Being mainly 'employed' is judged by the spells covered by employer's insurance. We construct sequences of statuses from age 30 to 44 for those who were born between 1958 and 1971 and who were employed in either the forest, metal, or chemical sectors at the end of year in which they turned 30. It should be noted that workers who have an ongoing employment contract are marked as being 'employed' while on parental and subsequent care leaves (in most cases the mother) during the follow-up, even if they are at home with the children in a particular year. Table 2 illustrates how our data selection spans different ages, cohorts, and years.

At each age, an individual's status is recorded at the end of the calendar year. Each individual thus has a career sequence consisting of 15 consecutive statuses between ages 30 and 44 . These career sequences allow us to analyze the degree of career stability and standardization across 14 birth cohorts and determine whether fragmentation has increased over time. We construct three types of individual career sequences. First, the simplest sequences contain only the main activity statuses (employed, unemployed, pensioned, inactive, or in education). These sequences allow analyzing the incidence of transitions in and out of employment during this career phase. 


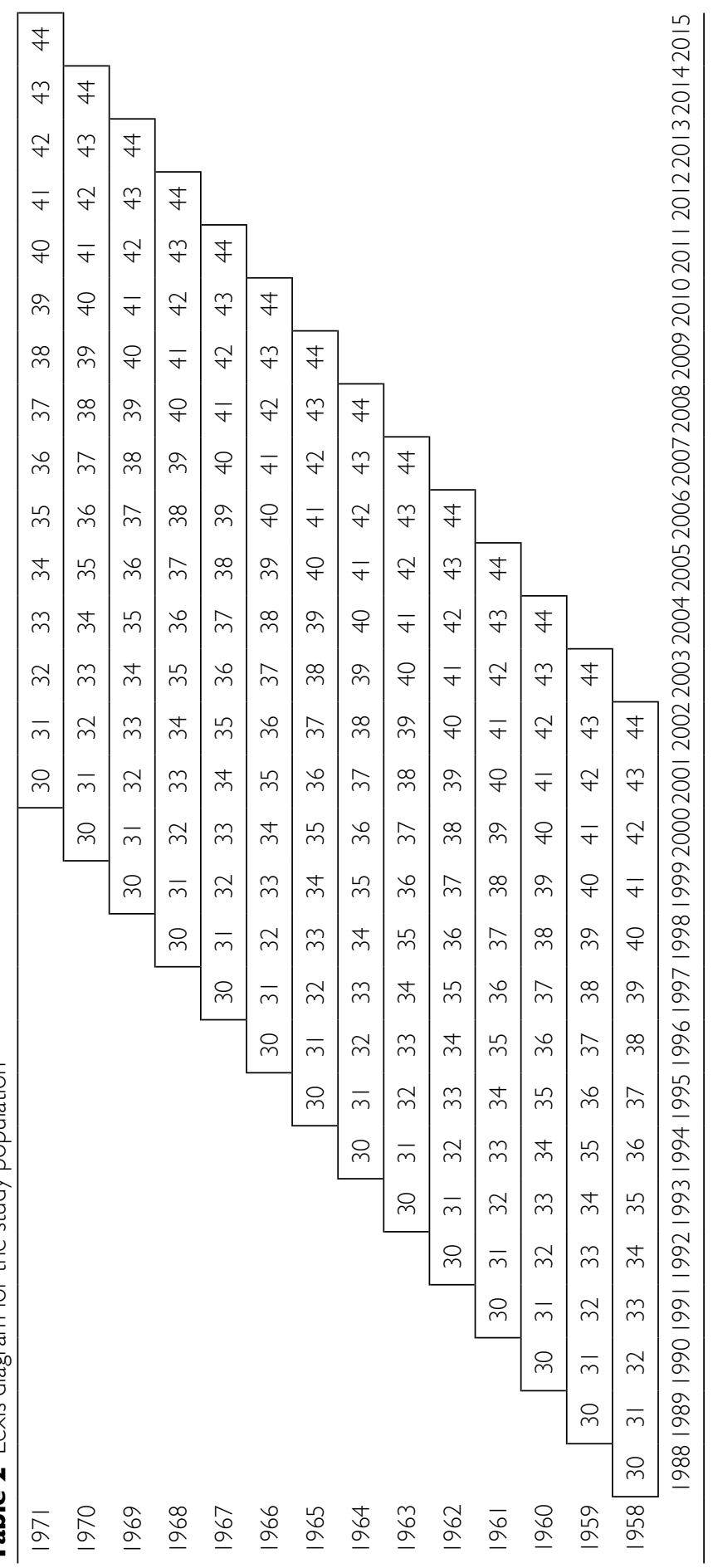


The second type of sequence consists of the same states as the first sequence but additionally includes a state for being employed in a different industry than the original industry of employment at age 30 (state 1). This means that all individuals start out as being employed in either forestry, metals or chemicals. If they move between those three sectors or become employed outside those (e.g., by moving to the services sector), their status changes to being employed in another industry (state 2). It is not specified to which industry the switch takes place, because we are mainly interested in analyzing whether employees remain within their own specialized field of economic activity or whether we can observe changes towards greater de-specialization and mobility between sectors. It is possible of course that someone returns to their original sector of employment, in which case they return to state 1.

The third type of sequence is the same as the first but includes job changes, as measured as changes between employers. To do so, we use the establishment-level identifiers in the data. If the establishment code changes within an individual sequence, we assume that person has changed jobs to a different employer. Each new job is included in the sequences as a new state. Whereas a majority of the study population works in one or two different jobs only, there are cases of those who hold 12 or 13 different jobs during the 15-year follow-up period. These sequences allow estimating the degree of job stability and mobility. Unfortunately, it is not possible to distinguish between voluntary job-to-job transitions and involuntary dismissals (Bachmann \& Felder 2018).

The methods we use promote the idea of looking at labor markets and work careers holistically instead of focusing on single transitions (Aisenbrey \& Fasang 2010; Möhring 2016). Applying statistical techniques from the family of sequence analysis, three indicators of career fragmentation are deployed to investigate whether careers in the forestry, metal, and chemical industries have destabilized and de-standardized across cohorts.

First, we consider whether stable employment has become a less common career type than before. To do so, we use sequence and cluster analysis to identify career typologies. We apply sequence analysis with Longest Common Subsequence (LCS) distances to establish dissimilarities between individual sequences (Elzinga \& Studer 2015; Gabadinho et al. 2009). The advantage of LCS is that it emphasizes the importance of the longest spell spent in a particular state (Studer \& Ritschard 2016). This is relevant for our study, as we are interested in deviations from what we consider a 'standard' or 'traditional' career, namely permanent employment with a single employer and in a single industry.

We perform sequence and cluster analysis only for sequences that include changes in industries and jobs, as they are the most relevant for the aims of our study. We apply Ward's clustering method. For the sequences including changes in industry we decide upon a solution of eight clusters. This solution performs well in terms of cluster quality indicators Average Silhouette Width $(\mathrm{ASW}=0.55)$ and Point Biserial Correlation $(\mathrm{PBC}=0.80)$ (Studer 2013). Whereas solutions with six or seven clusters scored somewhat better on ASW, we decided on eight clusters because it showed relevant differences between patterns where switches between industries take place. For the sequences including job changes, the optimal cluster solution was five (ASW $=0.39, \mathrm{PBC}=0.67$ ). For both sequence types, the clusters are discussed in the Results section below.

Second, we calculate Elzinga's sequence turbulence indicator for each of the three sequence types (including statuses only, including industry changes and including job changes). Turbulence is a measure for within-sequence complexity (Elzinga 2010; Elzinga \& Liefbroer 2007). For each sequence $x$, turbulence $T$ can be calculated as: 


$$
T(x)=\log _{2}\left(\phi(x) \frac{S_{t, \max }^{2}(x)+1}{S_{t}^{2}(x)+1}\right)
$$

where $s_{t}^{2}$ stands for the variance of the state-duration and $s_{t, \max }^{2}$ is the maximum value that this variance can take based on the total length of the sequence. This maximum is calculated by:

$$
S_{t, \max }^{2}=(n-1)(1-\bar{t})^{2}
$$

with $\bar{t}$ representing the mean consecutive time spent in each of the distinct states and $n$ is the length of the distinct state sequence (Gabadinho et al. 2009). Put simpler, this indicator is based on the number of transitions within a sequence and the length of each spell spent in a certain state. The more turbulent the sequence, the less predictable the career can be considered. The higher the indicator, the more complex and unstable the career is assumed to be. An increase in turbulence across cohorts indicates destabilization. We investigate whether careers have destabilized by the three industries, genders, and levels of education (see descriptive statistics in Table 1). Level of education is divided into three categories: lower (no formal degree or lower secondary education only), intermediate (upper secondary or lower tertiary), and higher (tertiary and beyond).

Third, we investigate whether heterogeneity has increased between individual careers, i.e. whether there are signs of career de-standardization. Here, we use a state entropy indicator that measures the dispersion between states at each age. It is calculated by:

$$
h\left(p_{1}, \ldots, p_{s}\right)=-\sum_{i=1}^{s} p_{i} \log \left(p_{i}\right)
$$

where $p_{i}$ is the proportion of cases in state $i$ at each time point and $s$ represents the possible number of states (Gabadinho et al. 2009). Entropy can take values between 0 and 1 , where high values mean high dissimilarity between individuals and low entropy means that a large proportion of the population is in the same state at a certain age. An increase in entropy across cohorts indicates de-standardization of careers. We calculate the state entropy for each of the three sequence types at each age between 30 and 44 for five groups of consecutive birth years: 1958-1960, 1961-1963, 1964-1966, 1967-1969, and 1970-1971.

All cohort participants are selected to the data at the age of 30 and followed up until the age of 44 .

\section{Results}

Figure 3 shows the state distribution plots for the three types of career sequences: with labor market statuses only (3a), with changes in industries included (3b), and with changes between jobs included (3c). Age is plotted on the x-axes. The y-axes indicate the proportion of people within a certain state. At age 30 , the entire study population 
Figure 3(a) State distribution plot including changes between labor market statuses only.

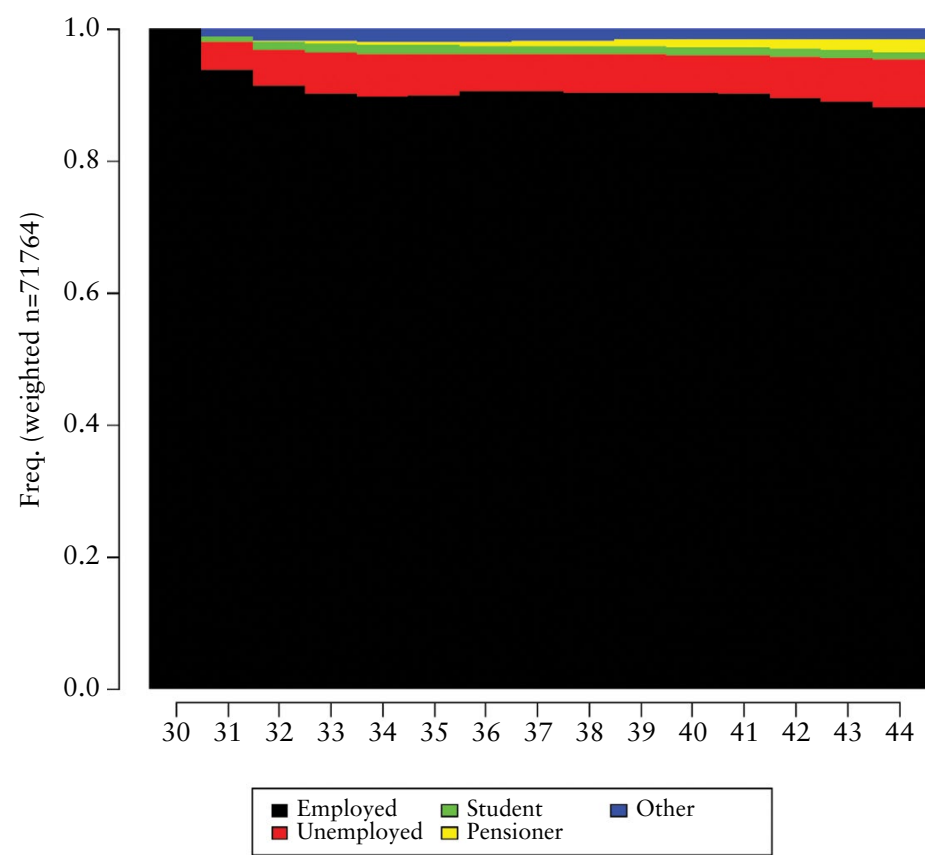

Figure 3(b) State distribution plot including changes between labor market statuses and industries.

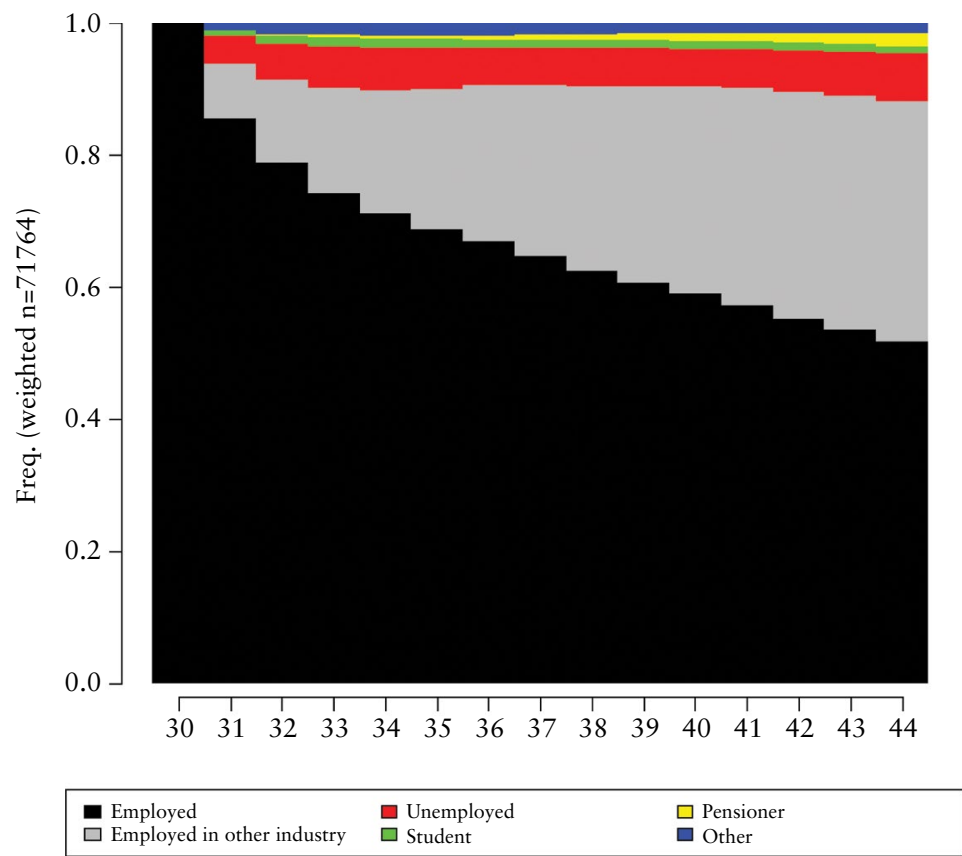


Figure 3(c) State distribution plot including changes between labor market statuses and jobs.

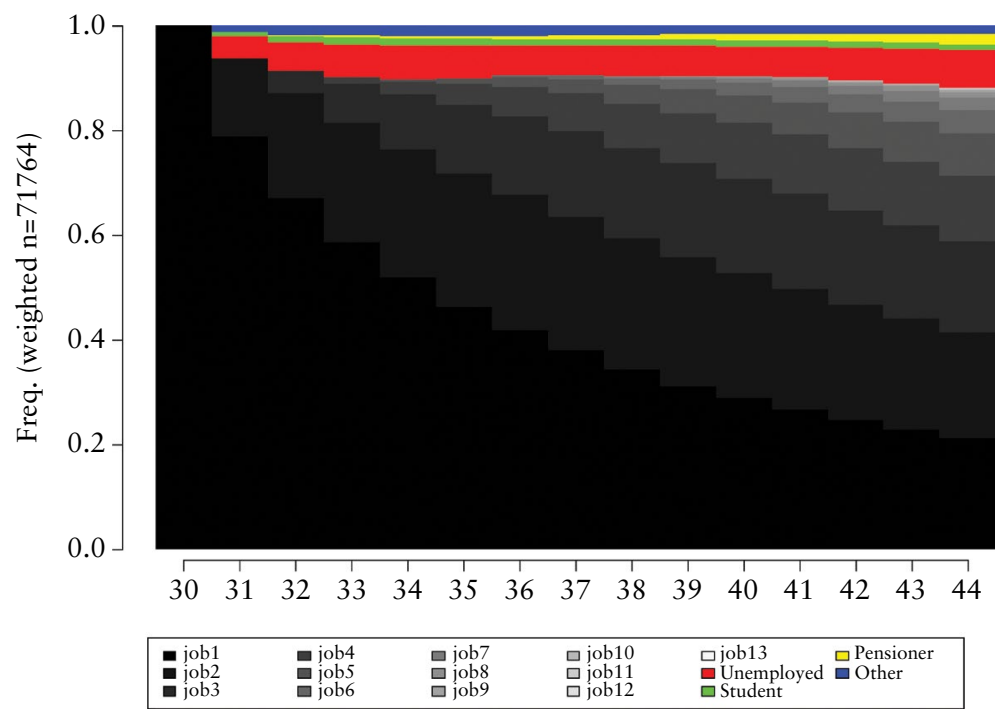

is employed in one of the three industries and with their first employer within this timeframe. It is important to note the relative stability of careers. At age 44 , around $90 \%$ of the study population is employed (3a), around $50 \%$ is employed in the same industry as at age $30(3 \mathrm{~b})$, and $20 \%$ is employed with the same employer (3c). Only a relatively small proportion of the population is unemployed or outside the labor market at each age.

Figure $4 \mathrm{a}$ shows the results for sequence and cluster analysis of careers including changes to a different industry than at age 30. The first and largest career type is named 'Employment in same industry'. This represents workers who for the most part remain employed in the same industry between ages 30 and 44 . There are two clusters that represent apparently permanent changes to a different industry. In the 'Industry switch' cluster this occurs at an earlier stage than in the 'Industry switch late' cluster. In the 'Return to same industry' cluster, people return to their original sector of employment after a period of employment elsewhere. There are three clusters characterized by unemployment. In the 'Long unemployment' cluster, the majority of individuals are in unemployment throughout most of the follow-up period. In 'Late unemployment', unemployment does not occur immediately, but sets in somewhere between ages 30 and 40 . Those in the 'Unemployment - industry switch' cluster mostly switch to a different industry after unemployment. Finally, there is a cluster consisting of those mainly 'Outside the labor market', either on a (disability) pension or by being otherwise inactive.

Figure $4 \mathrm{~b}$ shows the prevalence of each of these clusters among the different birth cohorts. In all cohorts the largest cluster is 'Employment in same industry'. Belonging to this cluster is less common among the oldest cohorts, but then peaks among employees born in 1962 and 1963. After that it declines again at the expense of the career types characterized by switches in industry. The other and more fragmented 
Figure 4(a) Career types including changes between industries, eight clusters, state distribution plots.
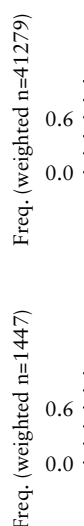

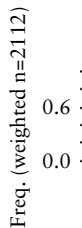

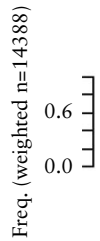

Employment same industry

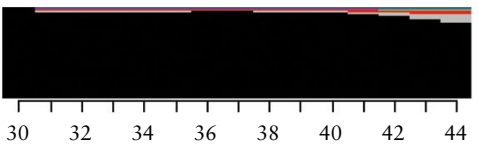

Unemployment - late

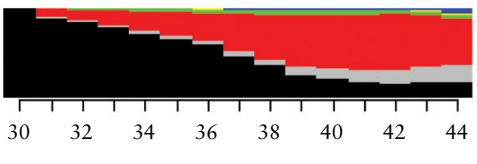

Outside the labour market

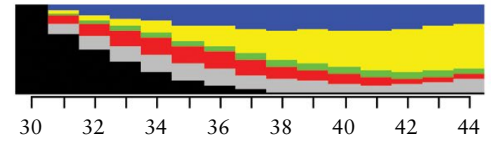

Industry switch

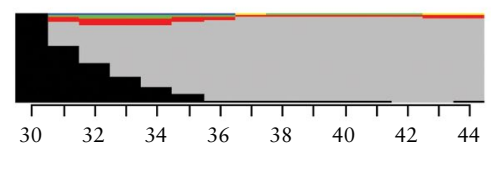

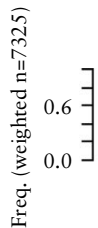

Industry swtich - late
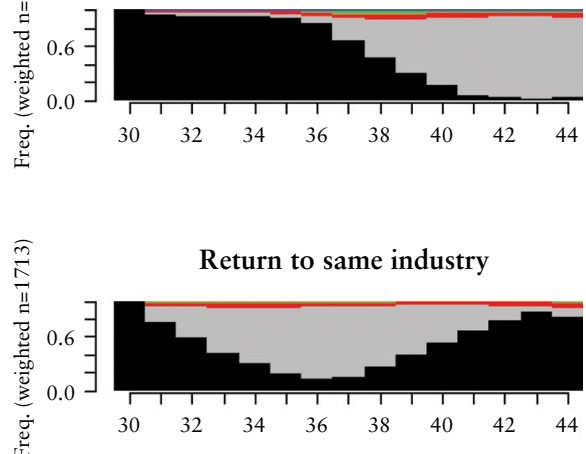

Return to same industry

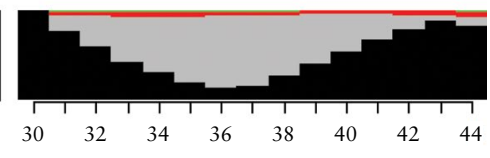

Unemployment - industry switch
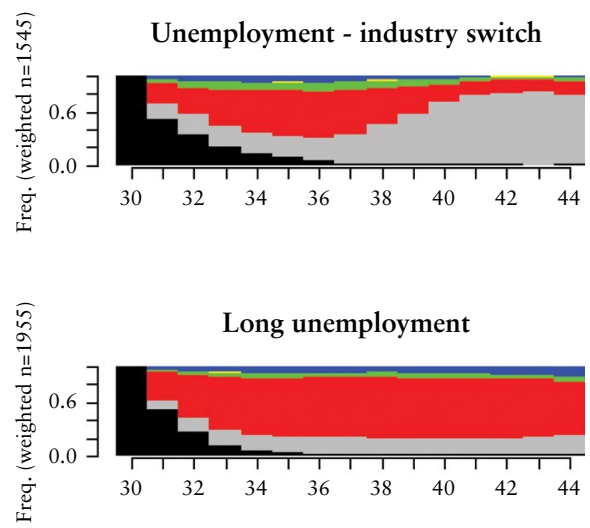

Employed $\quad \square$ Unemployed $\square$ Student $\square$ Other

career types are much less common and have declined across cohorts: in the 1958 cohort, they still account for $20 \%$ of all career types, yet in the 1971 cohort the figure was only around $10 \%$. These findings show little support for an overall trend toward career fragmentation. Rather, there seems to be a cyclical effect on having a steady job within the same industry: the oldest cohorts were most likely heavily affected by the recession in the early 1990s, whereas the youngest cohorts were affected by the financial crisis of the late 2000s. Yet, fragmentation did not occur in the sense of movements in and out of the labor market, but rather by finding work in a different sector.

Figure 5a shows the results for sequence and cluster analysis of career sequences including changes between employers. The largest cluster, 'Stable employment', is characterized by (almost) permanent employment with the same employer. There are two clusters where employees switch jobs but have longer employment spells with their 
Figure 4(b) Incidence of career types by birth year.

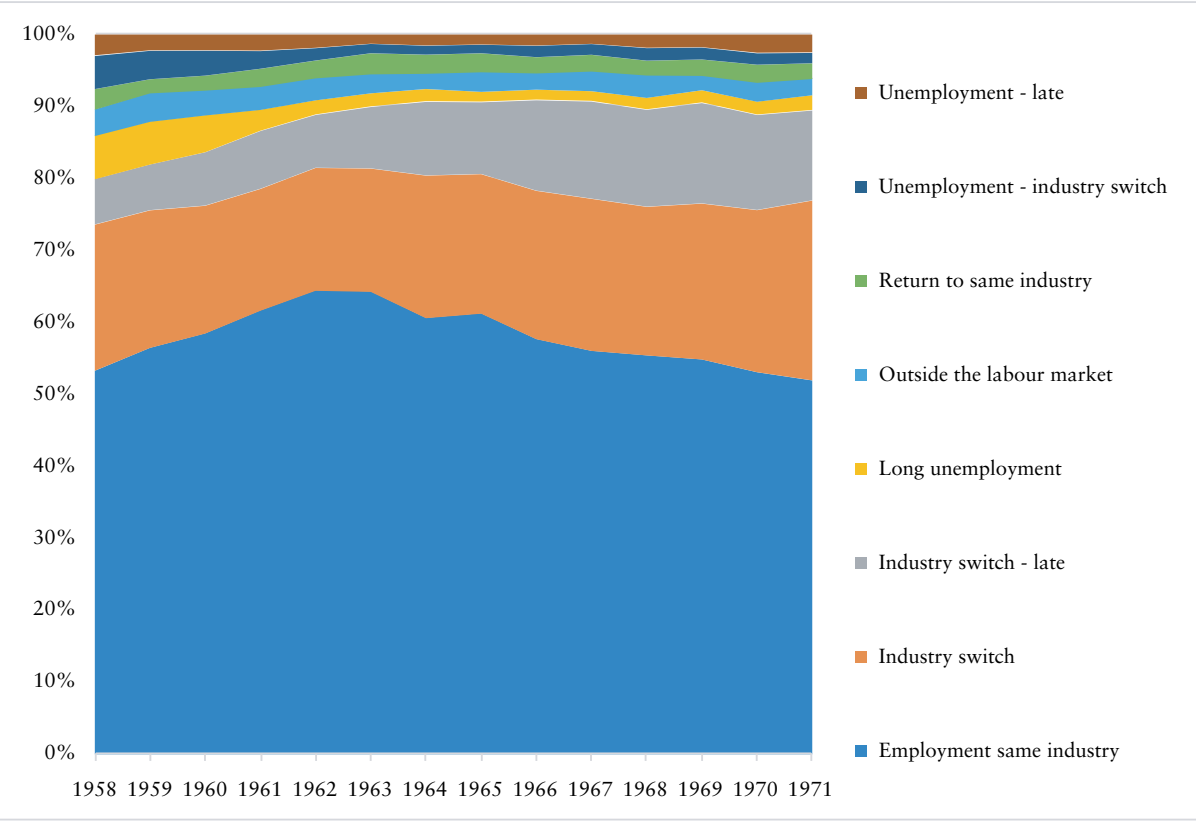

Figure 5(a) Career types including changes between jobs, five clusters, state distribution plots.
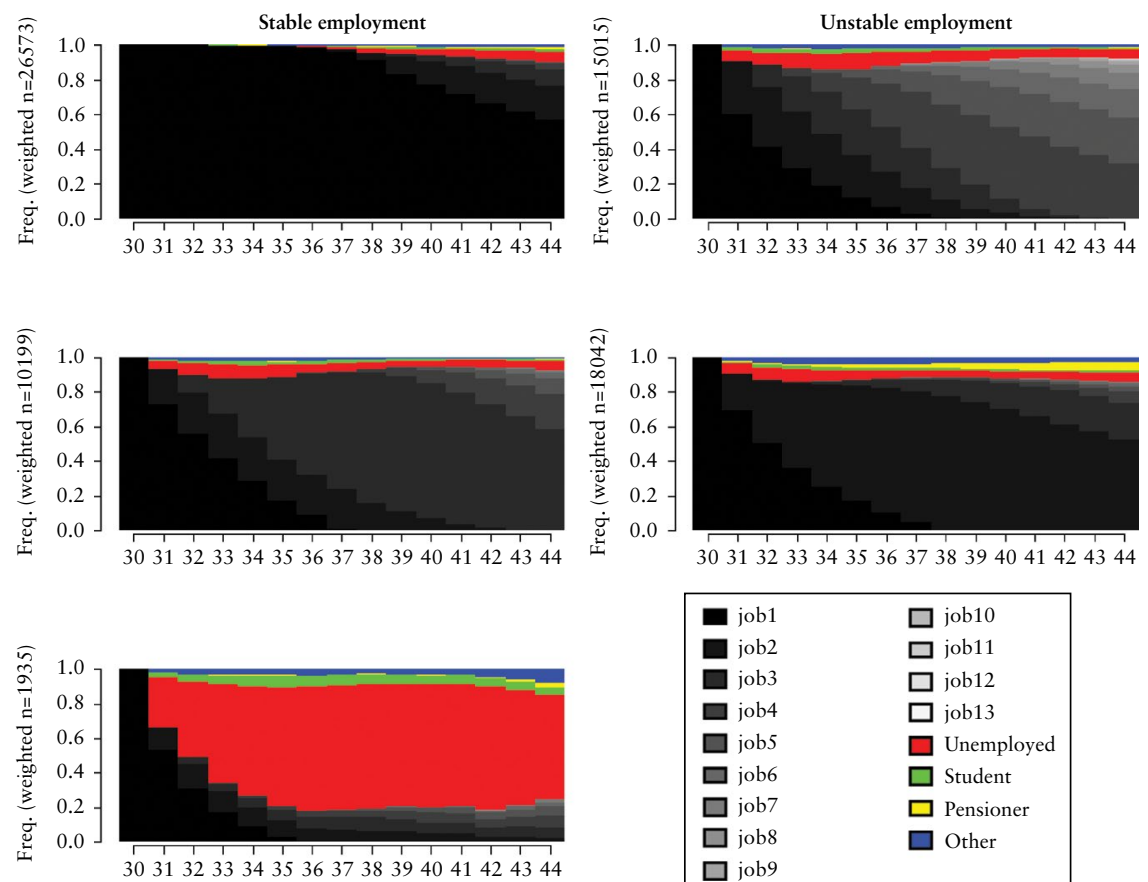

\begin{tabular}{|ll|}
\hline$\square$ job1 & $\square$ job10 \\
$\square$ job2 & $\square$ job11 \\
$\square$ job3 & $\square$ job12 \\
$\square$ job4 & $\square$ job13 \\
$\square$ job6 & $\square$ Unemployed \\
$\square$ job7 & $\square$ Student \\
$\square$ job8 & $\square$ Pensioner \\
$\square$ job9 & $\square$ Other \\
\hline
\end{tabular}


Figure 5(b) Incidence of career types by birth year.

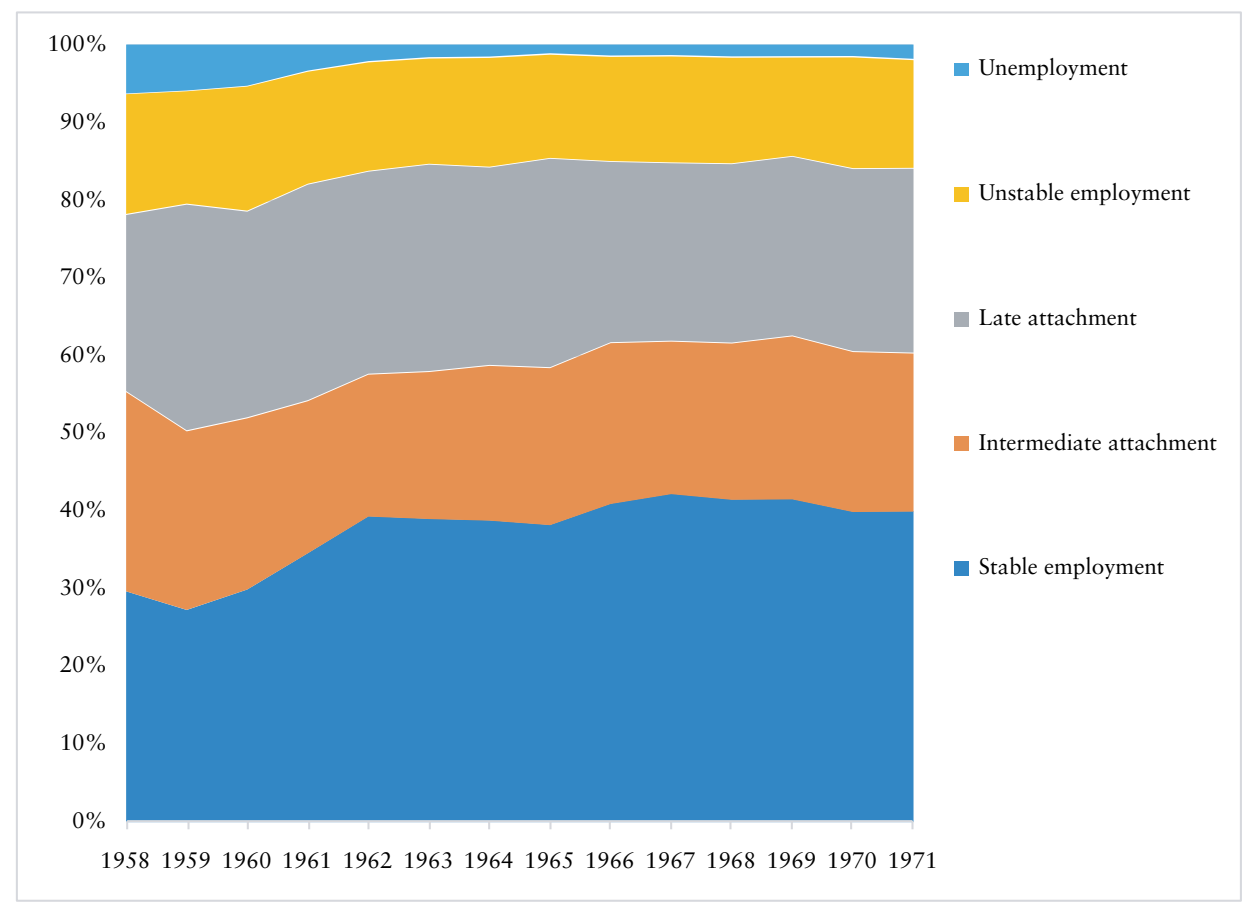

second ('Intermediate attachment') or third employer ('Late attachment'). Employees in the 'Unstable employment' cluster constantly change jobs. Finally, there is a cluster characterized by greater incidence of unemployment.

Figure $5 \mathrm{~b}$ represents the incidence of each of these clusters across birth cohorts. 'Stable employment' was least common in the 1958-1959 cohorts, but then increased and remained relatively stable from the 1962 cohort onwards. The 'Intermediate attachment', 'Late attachment' and 'Unstable employment' career types also remained relatively stable across the cohorts. The 'Unemployment' cluster diminished to a small percentage over time. Again, there are no signs of overall fragmentation. Employment patterns have been relatively stable since the oldest cohorts that were most affected by the 1990s recession, and careers characterized by unemployment have decreased. Yet, around $20 \%$ of the employees continue to experience unstable employment due to frequent job changes.

An examination of the results for the turbulence indicator allows us to identify the groups most affected by unstable careers. Figure 6 shows the average turbulence for each of the three career sequence types for each cohort and the three types of industry. Figure 6a shows that in all industries, the complexity of careers with labor market statuses only declined between the 1958 and 1963 cohorts and then began to rise again. When changes in industry (6b) and between jobs (6c) are included, this trend remains similar, yet the sector differences widen. Based on an examination of job changes $(6 \mathrm{c})$, it 
Figure 6(a) Sequence turbulence including changes in labor market status only, by birth year and industry.

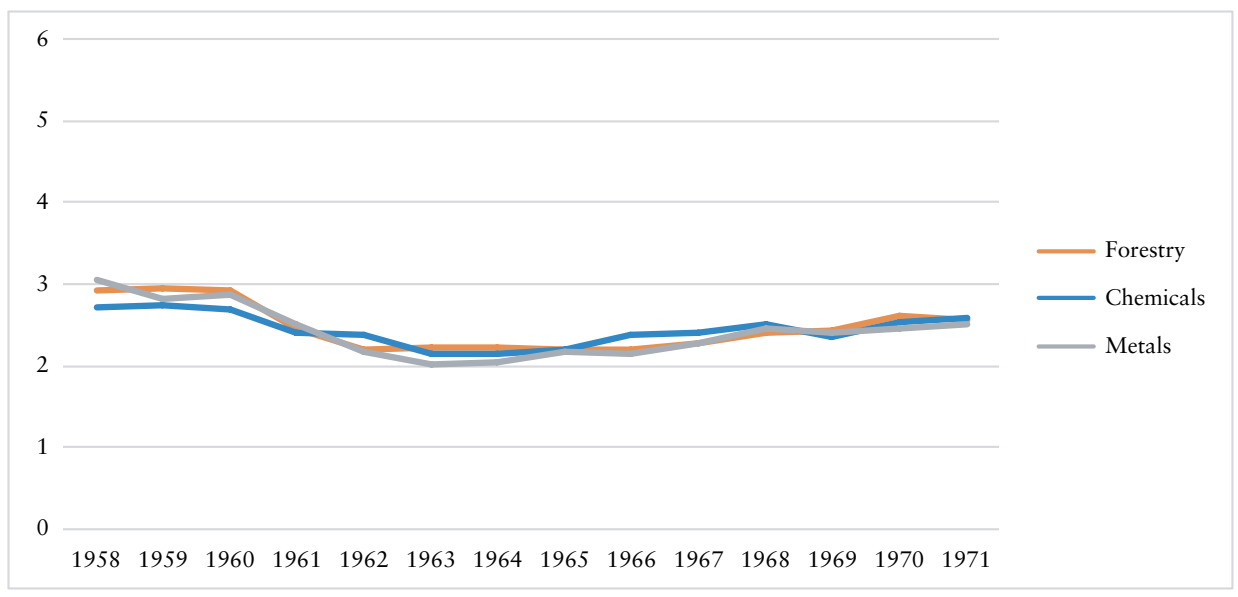

Figure 6(b) Sequence turbulence including changes in labor market status and between industries, by birth year and industry.

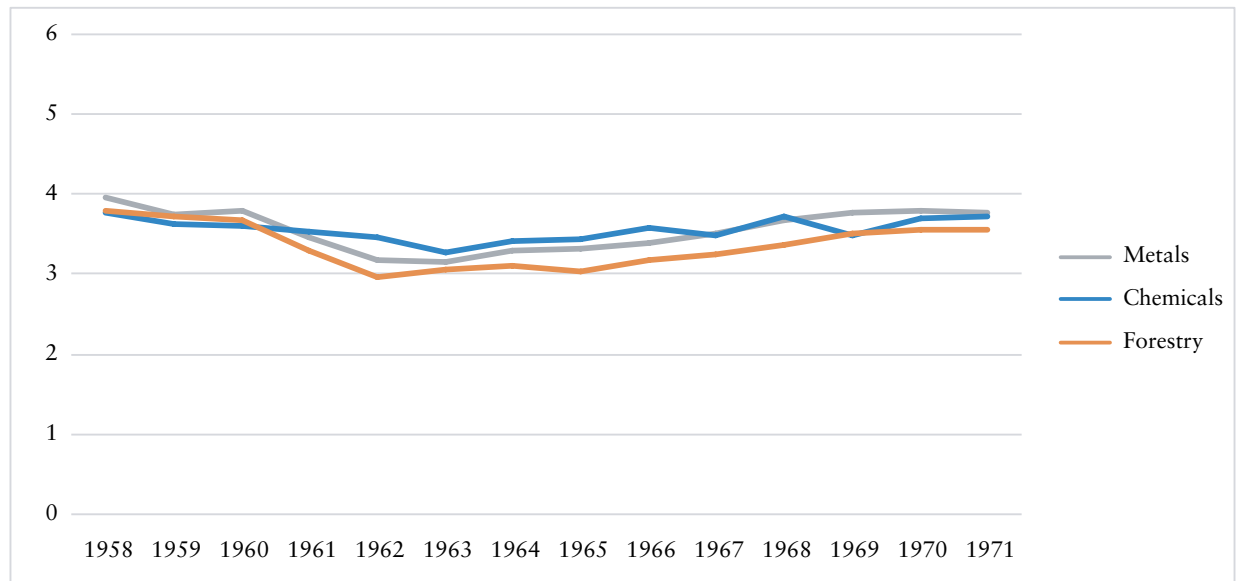

seems that those in the metal sector seem to have the least stable and those in the forestry industry the most stable careers.

Figure 7 shows the differences in turbulence between men and women. Women's careers are more unstable than men's, yet the gap with men's career stability remains virtually unchanged when changes between industries $(7 \mathrm{~b})$ and jobs $(7 \mathrm{c})$ are added. This indicates that women's more unstable careers are mainly due to the longer period of time spent outside employment, most likely as a result of taking time off for child care. Women do not switch industries or jobs more or less often than men.

Figure 8 shows the differences in career turbulence by level of education. Here, we see two interesting phenomena. First, the career stability of those with lower and intermediate 
Figure 6(c) Sequence turbulence including changes in labor market status and between employers, by birth year and industry.

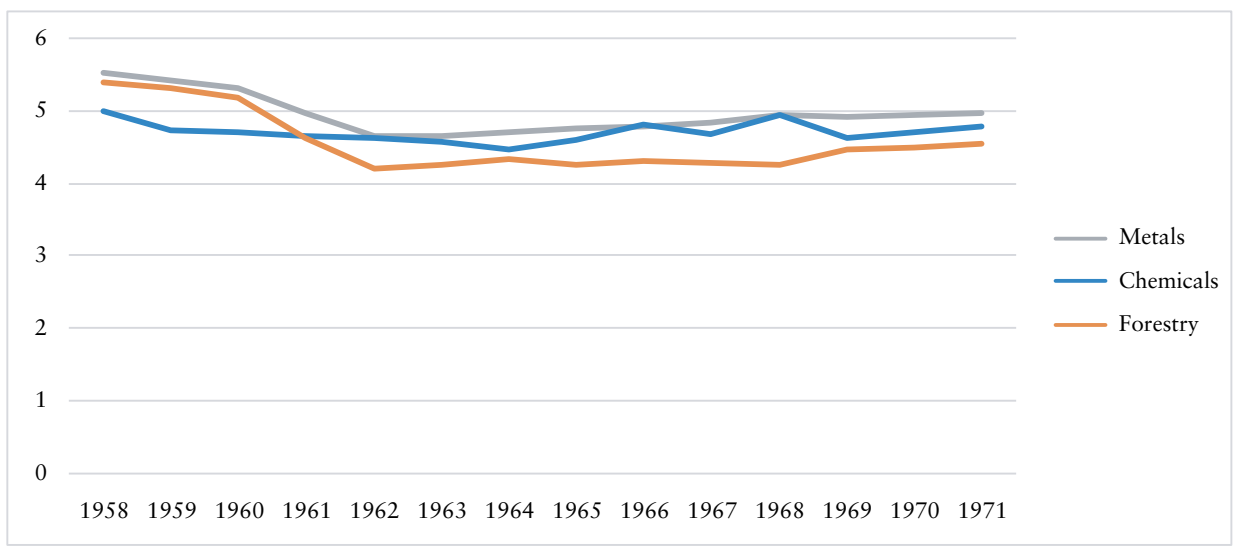

Figure 7(a) Sequence turbulence including changes in labor market status only, by birth year and gender.

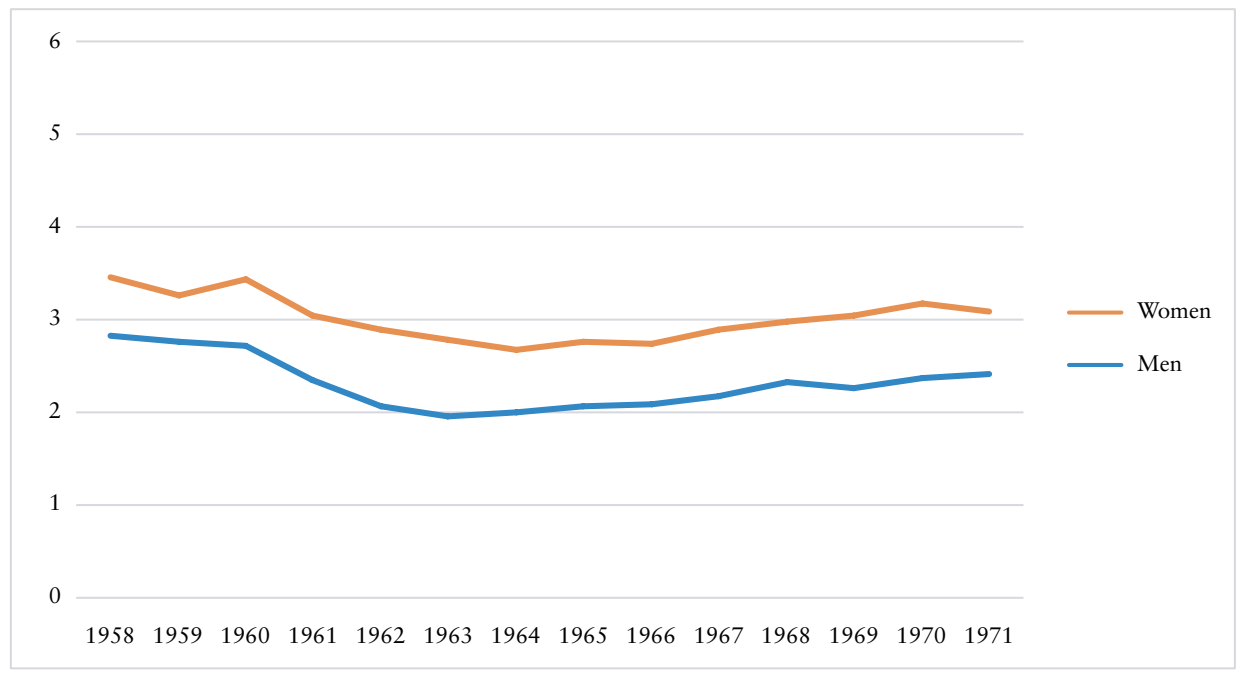

education seems to fluctuate more over time, while that of those with higher education is rather constant for each of the three career sequence types ( $8 \mathrm{a}-\mathrm{c})$. Second, higher educated employees have the lowest career instability when only labor market statuses are considered $(8 \mathrm{a})$ and the highest career stability when job changes are included in the analysis (8c). This finding suggests that those with higher education run a lower risk of spending time outside the labor market, whereas they are the most mobile in the labor market and change jobs more often than those with intermediate and lower education.

Finally, Figure 9 indicates changes in the heterogeneity between individual careers at each age and for five cohort groups. In all cases entropy is zero at age 30, because 
Figure 7(b) Sequence turbulence including changes in labor market status and between industries, by birth year and gender.

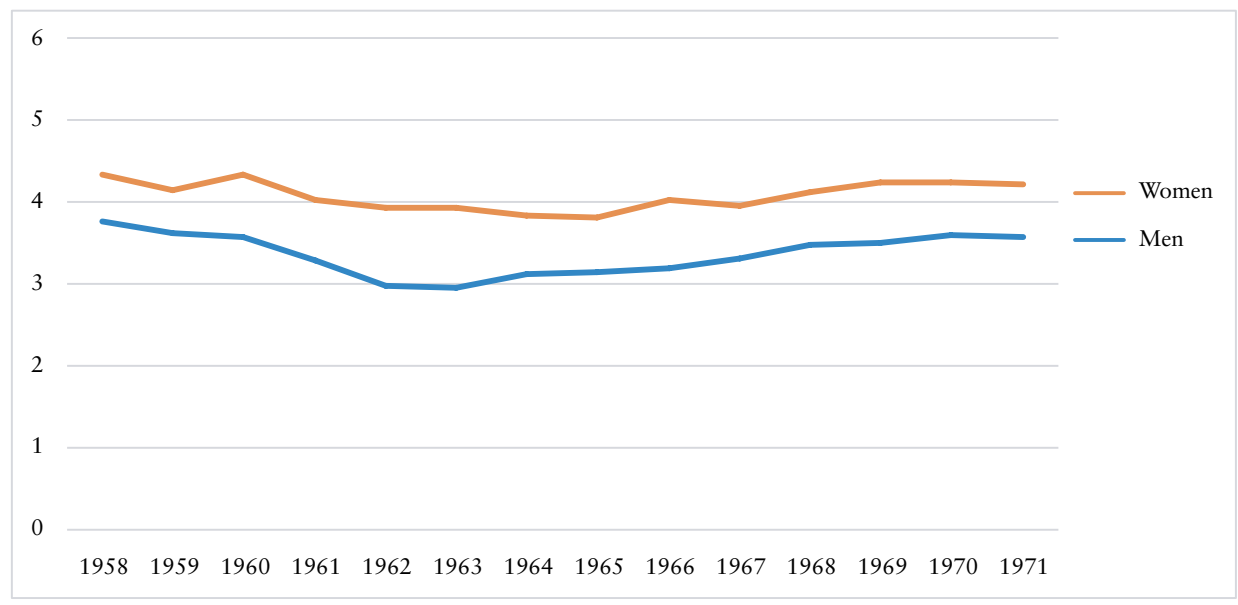

Figure 7(c) Sequence turbulence including changes in labor market status and between employers, by birth year and gender.

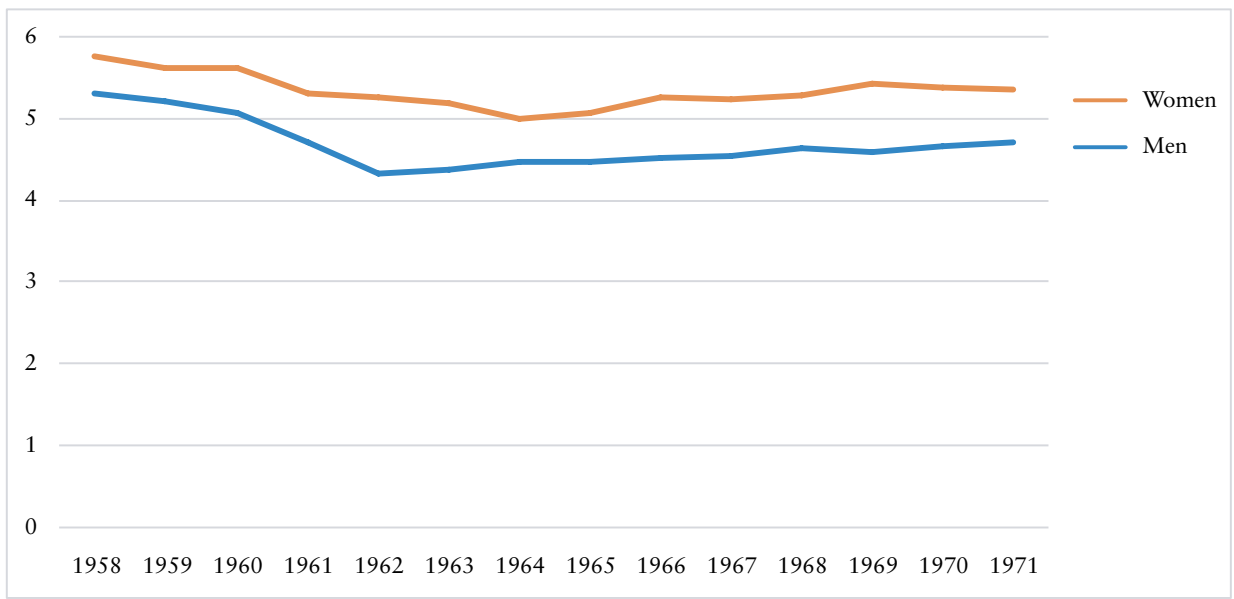

the entire study population is in the same state (employed, in the same industry and with the same employer). The entropy then rises sharply. In the case of career sequences with only labor market statuses (9a) and with industry changes (9b) included, heterogeneity reaches its peak for the oldest cohort at ages 33-35, after which it stabilizes at a somewhat lower level. Among the younger cohorts, heterogeneity stabilizes at lower levels, although in the youngest cohort there is a peak at around ages 38-39. For all three types of career sequences, there seem to be no substantial difference in state entropy by the time that the cohort turns 44 . These results are not indicative of career de-standardization across cohorts. In other words, these indicators do not lend evidence for the fragmentation of industrial careers either. 
Figure 8(a) Sequence turbulence including changes in labor market status only, by birth year and level of education.

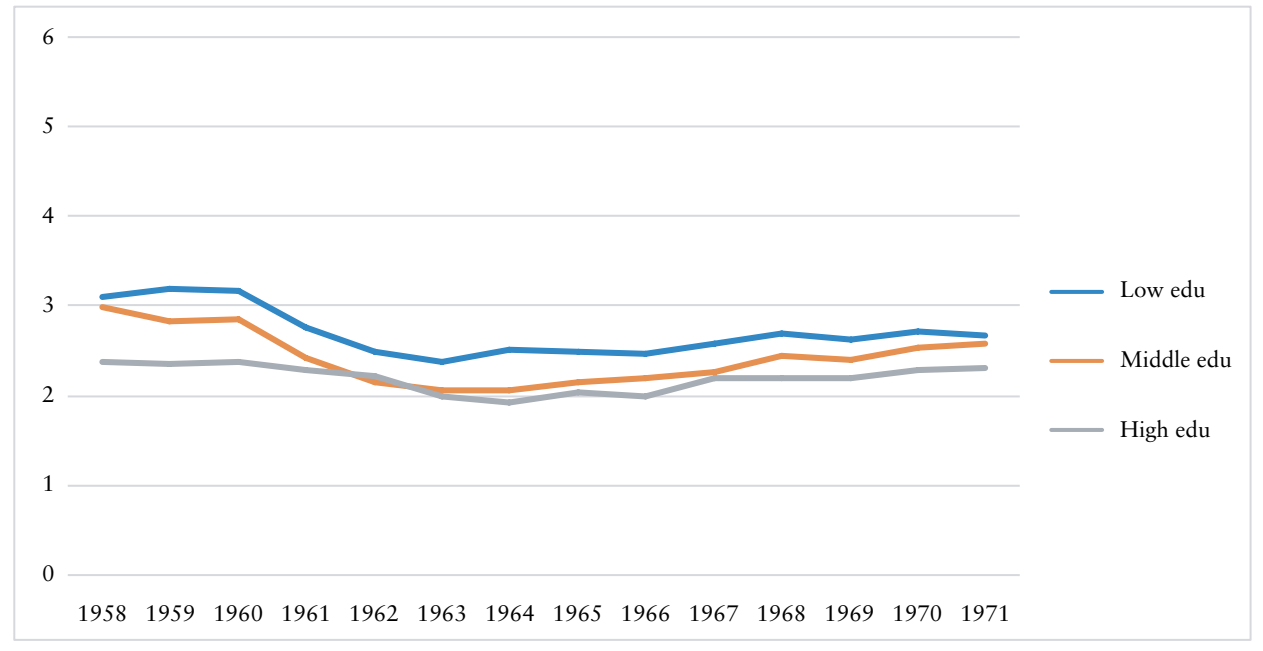

Figure 8(b) Sequence turbulence including changes in labor market status and between industries, by birth year and level of education.

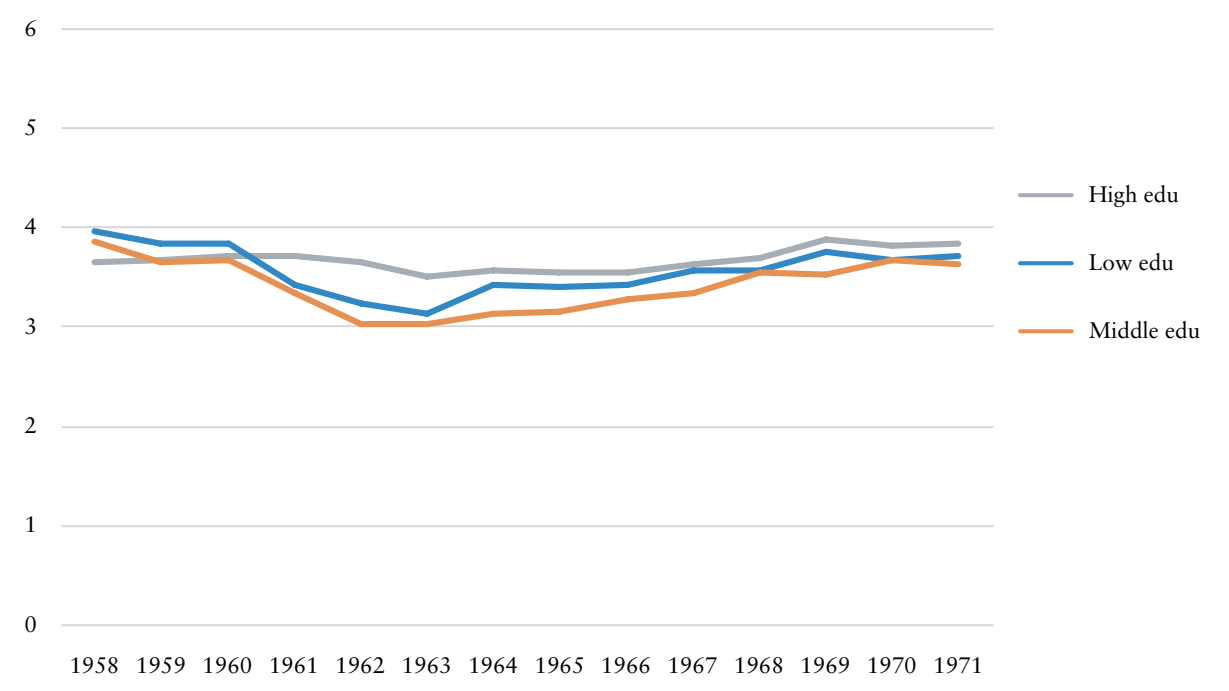


Figure 8(c) Sequence turbulence including changes in labor market status and between employers, by birth year and level of education.

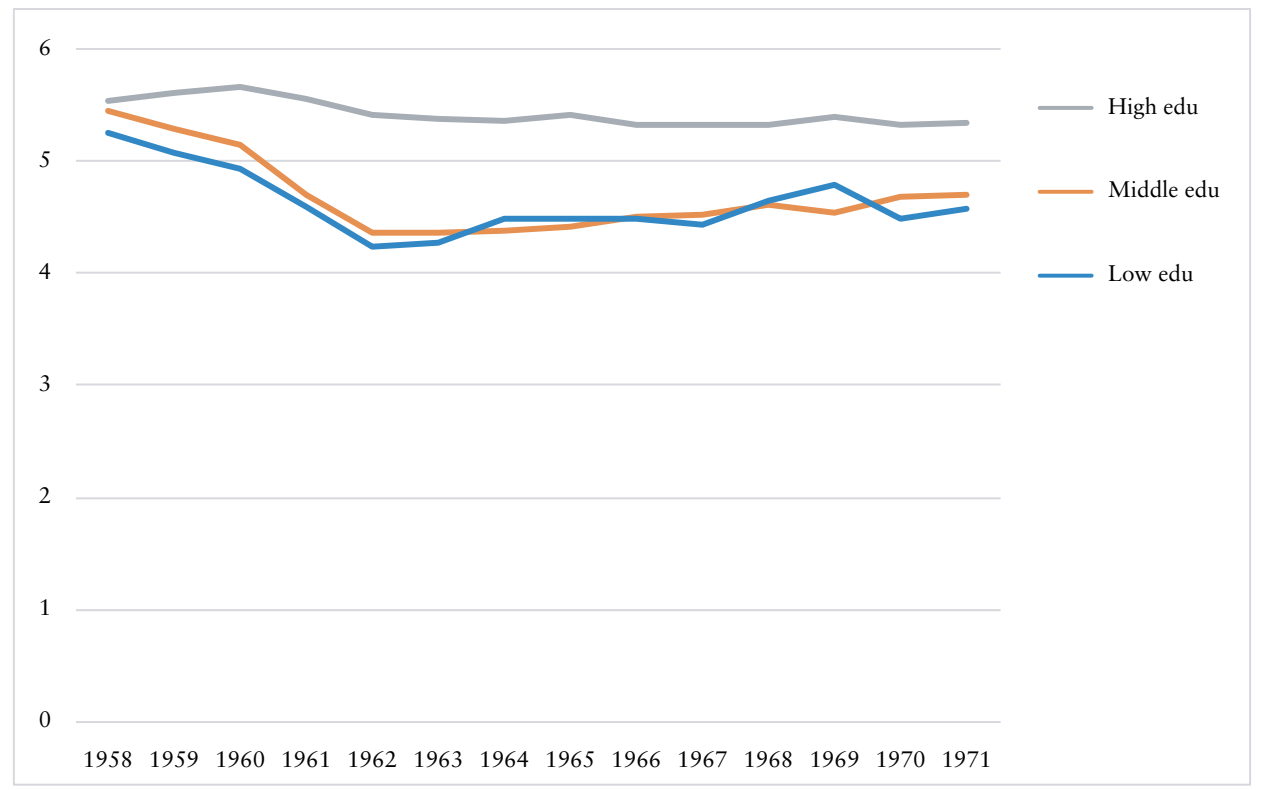

Figure $\mathbf{9 ( a )}$ State entropy including labor market statuses only, by age and cohort.

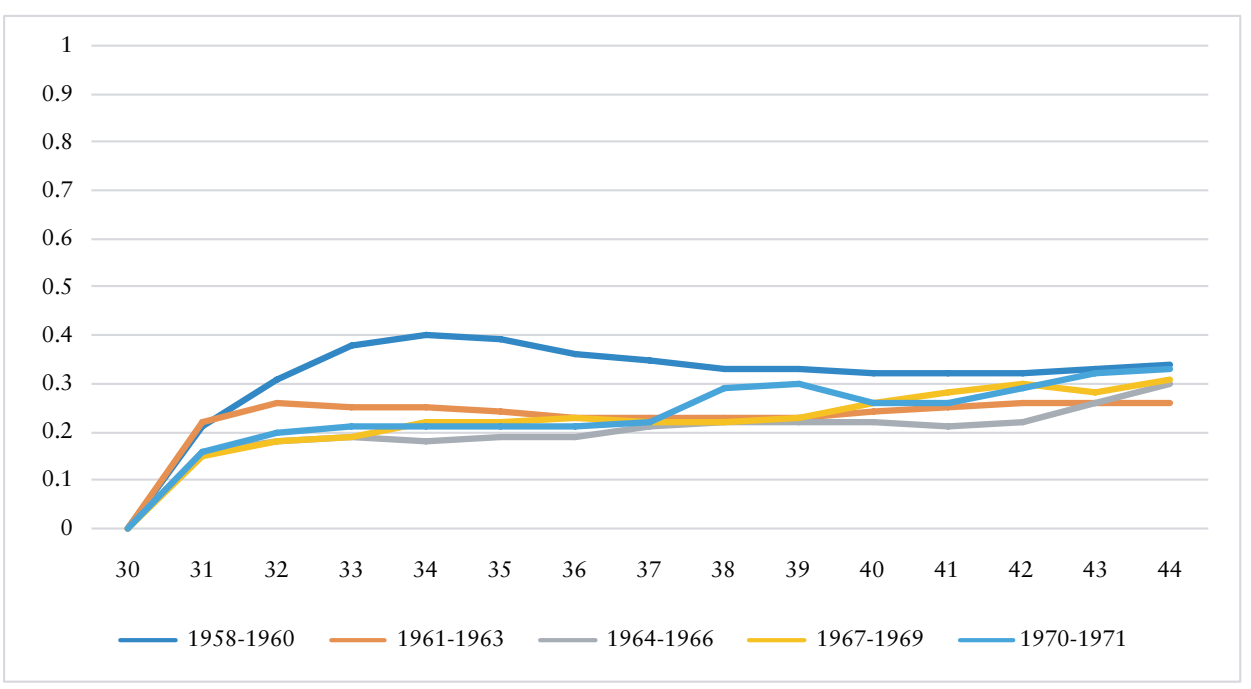


Figure 9(b) State entropy including labor market statuses and industry changes, by age and cohort.

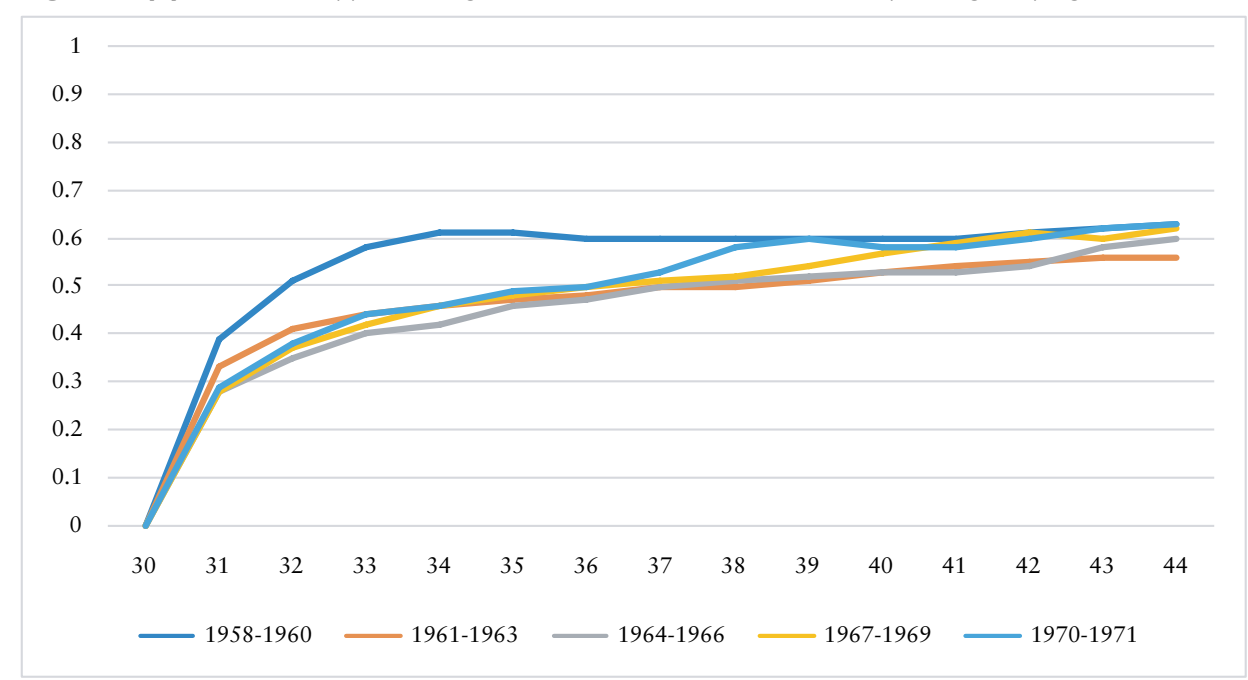

Figure 9(c) State entropy including labor market statuses and job changes, by age and cohort.

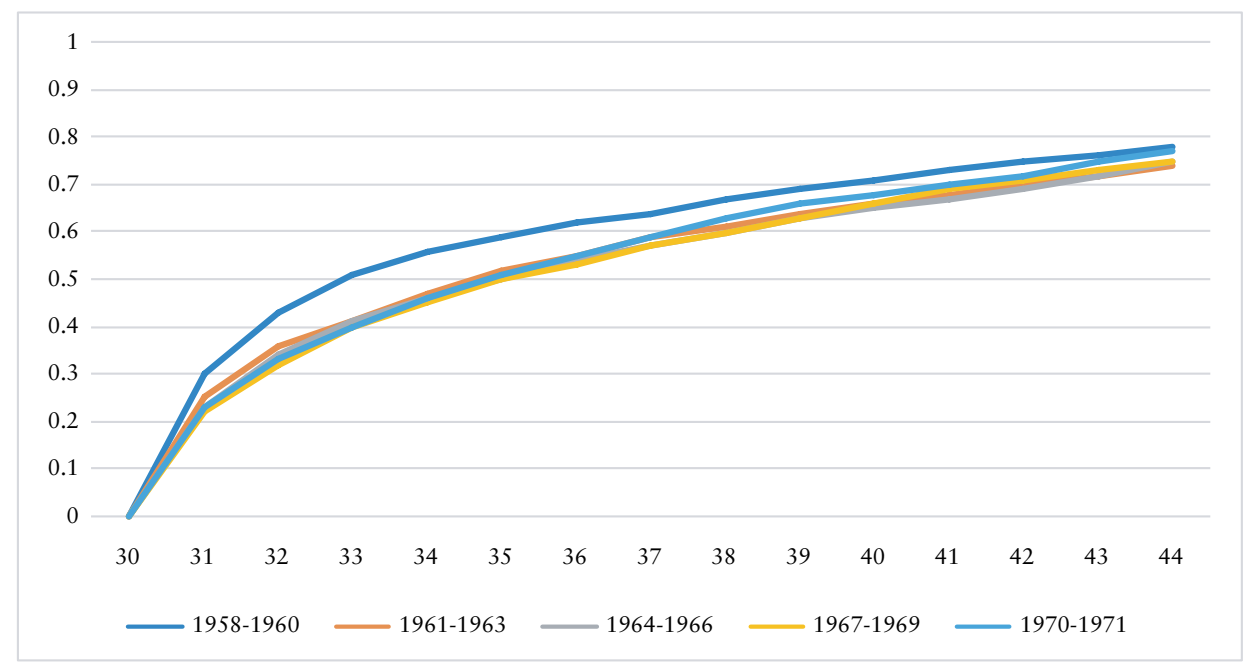

\section{Summary and conclusions}

In this article, we have analyzed the work careers of 14 cohorts of Finnish employees in the forest, metal, and chemical industries since the late 1980s. Industrial employees' careers are obviously not in a state of inertia, but we found no evidence of major career fragmentation across the cohorts studied. The results suggest that cyclical effects, that is, economic crises and the associated rises in unemployment, continue to remain the dominant driver of career instability. The crisis of the 1990s had particularly adverse effects on industrial workers' careers. This is seen in our findings in that the sequence 
turbulence indicator peaked among the cohorts born in 1958-1960, who were followed up in the years around the 1990s recession. Again, the indicator somewhat increased among the most recent cohorts followed up in relation to the financial crisis after 2008. Despite these disruptions, industrial careers have remained surprisingly stable.

However, this is not to say that careers in Finnish industry are immune to fragmentation. According to theories of job polarization, global competition (labor market deregulation), deindustrialization (a shift from manufacturing to services), and technological development (automation and digitalization) are all affecting employment in occupations in the middle of the skill distribution. These developments have to a large extent affected export industries - which of course have themselves actively contributed to these developments. Yet the underlying mechanisms often remain undiscussed: how does technological change translate into changes in employment and careers?

Within individuals work tasks, there is an empirically observed 'shift toward analytical and interactive activities and away from cognitive and manual routine tasks' (SpitzOener 2006, p. 236), leading to propositions of job polarization that should swell the upper and lower ends of the occupational skill distribution. Yet within jobs, workplace tasks are adjusted to and employees adjust to the new skill requirements: firms' productivity and competitiveness are boosted; and hence the demand for labor in new sectors and occupations is created at the macroeconomic level and 'large job losses remain unlikely' (Arntz et al. 2016, p. 23-24). Instead of career outcomes, therefore, there may be changes in industrial job tasks.

Another explanation can be sought from the tendency toward 'deregulated flexibility' (Allvin et al. 2013) in the organization of work in the industries concerned (as discussed in connection with Figure 2). As a result of declining overall employment rates, probably due to the outsourcing of services during the time span of our analysis (Figure 2), it is possible that the structure of the workforce directly employed by industrial firms has changed between the cohorts. In the cohorts born toward the end of the time span covered in our analysis, the number of low-skilled workers directly employed by industrial firms may have fallen, leaving only the core labor force in place. This core labor force may be increasingly competent and involved in developing new technology, for example, shaping their own opportunities regarding career stability. Unfortunately, the ISCO occupational classification is not available for all the years under study so that we could compare our industrial employee cohorts in more detail. Another underlying process is the potential risk faced by lower-level white-collar employees of being replaced by automation or higher-skilled employees.

Given the high overall share of those employed at the age of 44 in all cohorts, there is a strong line of continuity in Finnish industrial employees' careers. We are not in the position to explore major disruptions or abnormalities in their careers, other than that caused by the recession of the early 1990s. The same theme of continuity is also evident in the old drivers of segmentation between employees at different skill levels. Namely, employees with the lowest educational level showed the highest turbulence in employment status, that is, the largest number of transitions between employment and unemployment at all points of time. Highly educated employees, for their part, were most mobile in terms of changing employers, which can be interpreted as voluntary job-to-job transitions (see Bachmann \& Felder 2018), without any increase in unemployment. Another continued driver of segmentation is gender: women were much more likely to remain outside employment. We assume that women were more often in more

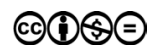


contingent working conditions in lower occupational categories, which is most typically the case in the industrial sector (Kauhanen \& Napari 2011).

Despite some unemployment and frequent job-switching, industrial employees were mobile but able to find new jobs, a result that is in line with earlier findings that show surprisingly high rates of re-employment for unemployed routine workers (Böckerman et al. 2012) and those laid off (Jolkkonen et al. 2012). Nevertheless, our results indicate that employees who belong to the 'primary segment' or the 'core labor force' in the industrial sector (men, highly educated) continue to have better opportunities to negotiate their position and change employers, whereas lower educated workers are more vulnerable to the effects of economic crises.

Although our study covers a relatively long period of time, it still seems too short to capture all the effects of economic fluctuations and demographic changes. Our analysis is to some extent affected by selection bias: as we chose to focus on employed industrial workers in different starting years (see Table 2; Figure $4 \mathrm{~b}$; Figure $5 \mathrm{~b}$ ), the share of those omitted is dependent on the overall unemployment rate. Cohorts who entered our analysis in the early 1990s, i.e. during the deep recession, are a particularly selected group of employees. In the 1990s, the overall employment rate was at an exceptionally low level at around $60 \%$ (OSF, 2017a). In the future, we will continue our analyses by comparing the results to the different cohorts' overall labor market situation. Earlier studies have as yet found no evidence of an overall fragmentation of careers over time (Biemann et al. 2011; Hollister 2011; Van Winkle \& Fasang 2017).

Since the educational level of the cohorts (1958-1971; OSF, 2017b) included in our comparison has increased, one might have expected to see this period effect to stand out in the results and higher educated, younger cohorts become 'better-off' in terms of labor market outcomes. Overall, it is possible that the need for more advanced skills has increased in the employing firms, which would explain the stable career outcomes. At the firm level, recruitment and reward policies (Buchmann et al. 2010) as well as opportunities for on-the-job learning (Boockmann \& Steffes 2010) shape the opportunities that individuals have with regard to career development. In this study we did not estimate any statistical differences or explore interaction effects between cohorts and educational levels, and therefore in the future we need to look in closer detail at the cohort effects. Other background factors may also affect the seemingly stable careers of cohorts of industrial employees. In the future it is important that we examine establishment and firm-level factors more closely, namely the finances and technology and R\&D investments made by employing organizations. We may expect that the profound changes ongoing in the operating environment are in some way connected to new social divisions at the employee level, and that they also affect firms' survival and growth.

We also expect, however, that productivity gains, after investments in new technologies, will provide a stronger competitive advantage, fostering the organization's profitability and organic growth and therefore also benefiting individual employees' skill enhancement. When a company invests in technology and R\&D in particular, there may be a positive effect on job stability in so far as it increases individuals' employability by means of positive skills development (see discussion: Böckerman et al. 2012; Kerr et al. 2019). We assume that the overall stability of industrial employees' careers over time, as highlighted in our results, can mainly be explained by the accumulated knowhow, highly skilled staff, and long experience of high-standard product development in Finnish industrial firms. 


\section{Acknowledgments}

The financial support of the Finnish Work Environment Fund (117355) is gratefully acknowledged.

\section{References}

Aisenbrey, S. \& Fasang, A. (2010). New life for old ideas: The "second wave" of sequence analysis bringing the "course" back into the life course. Sociological Methods \& Research 38(3): 420-462. doi: https://doi.org/10.1177/0049124109357532.

Aisenbrey, S. \& Fasang, A. (2017). The interplay of work and family trajectories over the life course: Germany and the United States in comparison. American Journal of Sociology 122(5): 1448-1484. doi: https://doi.org/10.1086/691128.

Allvin, M., Aronsson, G., Hagström, T., Johansson, G. \& Lundberg, U. (2011). Work Without Boundaries: Psychological Perspectives on the New Working Life. Chichester: John Wiley $\&$ Sons.

Anxo, D., Fagan, C., Cebrian, I. \& Moreno, G. (2007). Patterns of labour market integration in Europe - A life course perspective on time policies. Socio-Economic Review 5(2): 233-260. doi: https://doi.org/10.1093/ser/mw1019.

Arnzt, M., Gregory, T. \& Zierahn, U. (2016). The Risk of Automation for Jobs in OECD Countries: A comparative Analysis. OECD Social, Employment and Migration Working Papers no. 189. Paris: OECD. doi: https://doi.org/10.1787/5jlz9h56dvq7-en.

Asplund, R., Barth, E., Lundborg, P. \& Misje Nilsen, K. (2011). Polarization of the Nordic labour markets. Finnish Economic Papers 24(2): 87-110. https://www.taloustieteellinenyhdistys. fi/images/stories/fep/fep22011/fep22011 asplund.pdf [retrieved 6 May 2020].

Autor, D. (2014) Polanyi's Paradox and the Shape of Employment Growth. Cambridge, Mass.: National Bureau of Economic Research, Working Paper 20485. https://www.nber. org/papers/w20485.pdf [retrieved 14 February 2020].

Bachmann, R. \& Felder, R. (2019). Job stability in Europe over the cycle. International Labour Review 157(3): 481-518. doi: https://doi.org/10.1111/ilr.12117.

Bárány, Z. \& Siegel, C. (2018). Job polarization and structural change. American Economic Journal: Macroeconomics 10(1): 57-89. https://www.aeaweb.org/articles?id=10.1257/ mac.20150258 [retrieved 6 May 2020].

Barone, C. \& Schizzerotto, A. (2011). Career mobility, education, and intergenerational reproduction in five European societies. European Societies 13(3): 331-345. doi: https:// doi.org/10.1080/14616696.2011.568248.

Becker, R. \& Blossfeld, H-P. (2017). Entry of men into the labour market in West Germany and their career mobility (1945-2008). A long-term longitudinal analysis identifying cohort, period, and life-course effects. Journal for Labour Market Research 50(1): 113-130. doi: https://doi.org/10.1007/s12651-017-0224-6.

Biemann, T., Fasang, A. \& Grunow, D. (2011). Do economic globalization and industry growth destabilize careers? An analysis of career complexity and career patterns over time. Organization Studies 32(12): 1639-1663. doi: https://doi.org/10.1177/0170840611421246.

Boockmann, B. \& Steffes, S. (2010). Workers, firms, or institutions: What determines job duration for male employees in Germany? ILR Review 64(1): 109-127. doi: https://doi. org/10.1177/001979391006400105.

Brückner, H. \& Mayer, K. U. (2005). De-standardization of the life course: What it might mean? And if it means anything, whether it actually took place? Advances in Life Course Research 9(1): 27-53. doi: https://doi.org/10.1016/S1040-2608(04)09002-1. 
Brzinsky-Fay, C. \& Solga, H. (2016). Compressed, postponed, or disadvantaged? Schoolto-work-transition patterns and early occupational attainment in West Germany. Research in Social Stratification and Mobility 46(A): 21-36. doi: https://doi.org/10.1016/j. rssm.2016.01.004.

Buchmann, M. C., Kriesi, I. \& Sacchi, S. (2010). Labour market structures and women's employment levels. Work, Employment and Society 24(2): 279-299. doi: https://doi. org/10.1177/0950017010362142.

Bukodi, E. \& Goldthorpe, J. H. (2011). Class origins, education and occupational attainment in Britain. European Societies 13(3): 347-375. doi: https://doi.org/10.1080/14616696.2 011.568259 .

Böckerman, P., Kauhanen, A. \& Maliranta, M. (2012). ICT and Occupation-based Measures of Organisational Change: Firm and Employee Outcomes. Working Papers No 2. Helsinki: ETLA, The Research Institute of the Finnish Economy. http://hdl.handle. net/10419/201217 [retrieved 6 May 2020].

Böckerman, P., Laaksonen, S. \& Vainiomäki, J. (2013). Is There Job Polarization at the Firm Level? Tampere: University of Tampere, School of Management, Tampere economic working papers, net series. https://trepo.tuni.fi/handle/10024/94484 [retrieved 3 February 2020].

Cech, E. A. \& Blair-Loy, M. (2019). The changing career trajectories of new parents in STEM. PNAS 116(10): 4182-4187. doi: https://doi.org/10.1073/pnas.1810862116.

Cirillo, V. (2018). Job polarization in European industries. International Labour Review 157(1): 39-63. doi: https://doi.org/10.1111/ilr.12033.

Elzinga C. H. (2010). Complexity of categorical time series. Sociological Methods \& Research 38(3): 463-481. doi: https://doi.org/10.1177/0049124109357535.

Elzinga, C. H. \& Liefbroer, A. C. (2007). De-standardization of family-life trajectories of young adults: A cross-national comparison using sequence analysis. European Journal of Population / Revue européenne de Démographie 23(3-4): 225-250. doi: https://doi. org/10.1007/s10680-007-9133-7.

Elzinga, C. H. \& Studer, M. (2015). Spell sequences, state proximities, and distance metrics. Sociological Methods \& Research 44(1): 3-47. doi: https://doi.org/10.1177/ 0049124114540707.

Eurofound (2018). Overview of New Forms of Employment - 2018 Update. Luxembourg: Publications Office of the European Union. https://www.eurofound.europa.eu/sites/ default/files/ef publication/field ef document/ef18050en.pdf [retrieved 6 May 2020].

France, A. (2016). Understanding Youth in the Global Economic Crisis. Bristol: Policy Press.

Gabadinho, A., Ritschard, G., Studer, M. \& Müller, N. S. (2009). Mining Sequence Data in R with the TraMineR Package: A User's Guide. Geneva: University of Geneva, Department of Econometrics and Laboratory of Demography. http://mephisto.unige.ch/pub/TraMineR/ doc/TraMineR-Users-Guide.pdf [retrieved 20 October 2019].

Goos, M., Manning, A. \& Salomons, A. (2014). Explaining job polarization: Routinebiased technological change and offshoring. American Economic Review 104(8): 2509-2526. https://www.aeaweb.org/articles?id=10.1257/aer.104.8.2509 [retrieved 6 May 2020].

Halpern-Manners, A., Warren, R. J., Raymo, J. \& Nicholson, A. D. (2015). The impact of work and family life histories on economic well-being at older ages. Social Forces 93(4): 1369-1396. doi: https://doi.org/10.1093/sf/sov005.

Hollister, M. (2011). Employment stability in the U.S. labor market: Rhetoric versus reality. Annual Review of Sociology 37(1): 305-324. https://www.annualreviews.org/doi/ abs/10.1146/annurev-soc-081309-150042 [retrieved 6 May 2020]. 
Horemans, J. (2016). Polarisation of non-standard employment in Europe: Exploring a missing piece of the inequality puzzle. Social Indicators Research 125(1): 171-189. doi: https://doi.org/10.1007/s11205-014-0834-0.

Hyman, R. (2018). What future for industrial relations in Europe? Employee Relations 40(4): 569-579. https://www.emerald.com/insight/content/doi/10.1108/ER-02-2018-0056/full/ html.

Jolkkonen, A., Koistinen, P. \& Kurvinen, A. (2012). Reemployment of displaced workers The case of a plant closing on a remote region in Finland. Nordic Journal of Working Life Studies 2(1): 81-100. doi: https://doi.org/10.19154/njwls.v2i1.2353.

Järvinen, K-M., Pyöriä, P., Ojala, S., Lipiäinen, L. \& Saari, T. (2020). Työurien vakaus ja taantuma: yksityisen sektorin työntekijöiden työurapolut 2007-2015. [Career stability and recession: Private-sector employees' career trajectories, 2007-2015]. Työelämän tutkimus - Arbetslivsforskning 18(2): 81-99.

Kalela, J., Kiander, J., Kivikuru, U., Loikkanen, H. A. \& Simpura, J. (Eds.) (2001). Down from the Heavens, Up from the Ashes: The Finnish Economic Crisis of the 1990s in the Light of Economic and Social Research. Helsinki: Government Institute for Economic Research. https://www.doria.fi/bitstream/handle/10024/148630/j27-6.pdf? sequence=1\&isAllowed=y [retrieved 6 May 2020].

Kalleberg, A. L. (2018). Precarious Lives: Job Insecurity and Well-Being in Rich Democracies. Cambridge: Polity Press.

Kalleberg, A. L. \& Mouw, T. (2018). Occupations, organizations, and intergenerational career mobility. Annual Review of Sociology 44(1): 283-303. https://www.annualreviews. org/doi/abs/10.1146/annurev-soc-073117-041249.

Kauhanen, A. \& Napari, S. (2011). Gender Differences in Careers. Discussion Papers No 1241. Helsinki: ETLA, The Research Institute of the Finnish Economy. https://www.etla. fi/wp-content/uploads/2012/09/dp1241.pdf [retrieved 6 May 2020].

Kerr, S., Maczulskij, T. \& Maliranta, M. (2019). Within and Between Firm Trends in Job Polarization: The Roles of Globalization and Technology. Journal of Economic Geography. Online first. doi: https://doi.org/10.1093/jeg/lbz028.

Kohli, M. (2007). The institutionalization of the life course: Looking back to look ahead. Research in Human Development 3(3/4): 253-271. doi: https://doi.org/10.1080/15427 600701663122.

Kuitto, K., Salonen, J. \& Helmdag, J. (2019). Gender inequalities in early career trajectories and parental leaves: Evidence from a Nordic welfare state. Social Sciences 8(9): 1-16. https://www.mdpi.com/2076-0760/8/9/253 [retrieved 6 May 2020].

de Leeuw, E. D. \& Lugtig, P. (2015). Dropouts in longitudinal surveys. In Wiley StatsRef: Statistics Reference Online. doi: https://doi.org/10.1002/9781118445112.stat06661. pub2.

Lehndorff, S., Dribbusch, H. \& Schulten, T. (2018). European trade unions in a time of crises - An overview. In S. Lehndorff \& H. Dribbusch \& T. Schulten (Eds.) Rough Waters European Trade Unions in a Time of Crises. Brussels: ETUI, 7-38. https://www.etui.org/ Publications2/Books/Rough-waters-European-trade-unions-in-a-time-of-crises [retrieved 6 May 2020].

López-Andreu, M. \& Rubery, J. (2018). Austerity and women's employment trajectories in Spain and the UK: A comparison of two flexible labour markets. Economic and Industrial Democracy. Online first. doi: https://doi.org/10.1177/0143831X18760988.

Manzoni, A., Vermunt, J. K., Luijkx, R. \& Muffels, R. (2010). Memory bias in retrospectively collected employment careers: A model based approach to correct for measurement error. Sociological Methodology 40(1): 39-73. doi: https://doi.org/10.1111/j.14679531.2010.01230.x. 
Möhring, K. (2016). Life course regimes in Europe: Individual employment histories in comparative and historical perspective. Journal of European Social Policy 26(2): 124-139. doi: https://doi.org/10.1177/0958928716633046.

Nikulainen, T. \& Pajarinen, M. (2013). Industry Restructuring in the ICT Sector. What Does Labor Mobility Tell Us About Skill Relatedness and Knowledge Spillovers? Helsinki: ETLA, Working Papers No 17. https://www.etla.fi/wp-content/uploads/ETLA-WorkingPapers-17.pdf [retrieved 6 May 2020].

Official Statistics of Finland (OSF 2017a). Labour force survey [e-publication]. Employment and Unemployment 2017, 2 Employment and unemployment in 2017. Helsinki: Statistics Finland. http://www.stat.fi/til/tyti/2017/13/tyti $2017 \quad 13$ 2018-04-12 kat 002 en.html [retrieved 20 October 2019].

Official Statistics of Finland (OSF 2017b). Educational structure of population [e-publication]. 2017. Helsinki: Statistics Finland. http://www.stat.fi/til/vkour/2017/ vkour 2017 2018-11-02 tie 001 en.html [retrieved 20 October 2019].

Pavlopoulus, D. \& Vermunt, J. K. (2015) Measuring temporary employment. Do survey or register data tell the truth? Survey Methodology 41(1): 197-214. https://www150.statcan.gc.ca/n1/en/pub/12-001-x/2015001/article/14151-eng.pdf?st=DMRVU5fa [retrieved 13 September 2020].

Potter, J. (2015). Crisis at Work: Identity and the End of Career. Basingstoke: Palgrave Macmillan.

Pyöriä, P. (2006). Understanding Work in the Age of Information: Finland in Focus. Tampere: Tampere University Press, Acta Universitatis Tamperensis 1143. http://urn.fi/urn:isbn:951-44-6600-4 [retrieved 6 May 2020].

Pyöriä, P. \& Ojala, S. (2016). Precarious work and intrinsic job quality: Evidence from Finland, 1984-2013. The Economic and Labour Relations Review 27(3): 349-367. doi: https://doi.org/10.1177/1035304616659190.

Pyöriä, P., Ojala, S., Saari, T. \& Järvinen, K-M. (2017). The millennial generation: A new breed of labour? SAGE Open 7(1): 1-14. doi: https://doi.org/10.1177/2158244017697158.

Rasmussen, S., Nätti, J., Larsen, T. P., Ilsøe, A. \& Garde, A. H. (2019) Nonstandard employment in the Nordics - Toward precarious work? Nordic Journal of Working Life Studies 9(S6): 7-32. doi: https://doi.org/10.18291/njwls.v9iS6.114689.

Riekhoff, A-J. (2018). Extended working lives and late-career destabilisation: A longitudinal study of Finnish register data. Advances in Life Course Research 35(1): 114-125. doi: https://doi.org/10.1016/j.alcr.2018.01.007.

Rokkanen, M. \& Uusitalo, R. (2010). Changes in Job Stability - Evidence from Lifetime Job Histories. Working Papers 14. Helsinki: Government Institute for Economic Research. http://urn.fi/URN:ISBN:978-951-561-908-2 [retrieved 6 May 2020].

Rubery, J., Keizer, A. \& Grimshaw, D. (2016). Flexibility bites back: the multiple and hidden costs of flexible employment policies. Human Resource Management Journal 26(3): 235-251. doi: https://doi.org/10.1111/1748-8583.12092.

Salvatori, A. (2018) The anatomy of job polarisation in the UK. Journal for Labour Market Research 52(8): 1-15. doi: https://doi.org/10.1186/s12651-018-0242-z.

Schellenberg, C., Krauss, A., Hättich, A. \& Häfeli, K. (2016). Occupational career patterns over 30 years: predictors and outcomes. Empirical Research in Vocational Educational and Training 8(1): 1-22. doi: https://doi.org/10.1186/s40461-016-0042-z.

Soininen, T. (2015). Changing Expectations and Realities of Employment Stability Longitudinal Analysis on Tenures in Finland. Joensuu: University of Eastern Finland, Dissertations in Social Sciences and Business Studies 102. http://urn.fi/URN:ISBN: 978-952-61-1743-0 [retrieved 6 May 2020]. 
Spitz-Oener, A. (2006). Technical change, job tasks, and rising educational demands: Looking outside the wage structure. Journal of Labor Economics 24(2): 235-270. https://www. jstor.org/stable/10.1086/499972 [retrieved 6 May 2020].

Statistics Finland (2004) Use of Registers and Administrative Data Sources for Statistical Purposes: Best Practices of Statistics Finland. Helsinki: Statistics Finland. https://www. doria.fi/bitstream/handle/10024/136324/xksk45 $200400 \quad 2004$ dig.pdf? sequence $=1$ [retrieved 13 September 2020].

Statistics Finland (2020) Table 12bq Population aged 15 or over by level of education and gender, 1970-2018. Statistics Finland's PxWeb databases. http://pxnet2.stat.fi/PXWeb/ pxweb/en/StatFin/StatFin kou/ [retrieved 29 October 2020].

Stawarz, N. (2018). Patterns of intragenerational social mobility: An analysis of heterogeneity of occupational careers. Advances in Life Course Research 38(1): 1-11. doi: https:// doi.org/10.1016/j.alcr.2018.10.006.

Studer, M. (2013). WeightedCluster Library Manual: A practical guide to creating typologies of trajectories in the social sciences with R. LIVES Working Papers, 24. doi: https://doi. org/10.12682/lives.2296-1658.2013.24.

Studer, M. \& Ritschard, G. (2016). What matters in differences between life trajectories: A comparative review of sequence dissimilarity measures. Journal of the Royal Statistical Society: Series A (Statistics in Society) 179(2): 481-511. doi: https://doi.org/10.1111/ rssa.12125.

Van Winkle, Z. \& Fasang, A. (2017). Complexity in employment life courses in Europe in the Twentieth Century - Large cross-national differences but little change across birth cohorts. Social Forces 96(1): 1-30. doi: https://doi.org/10.1093/sf/sox032. 